\title{
Biciliated ependymal cell proliferation contributes to spinal cord growth
}

\author{
Clara Alfaro-Cervello1,2,§, Mario Soriano-Navarro², Zaman Mirzadeh ${ }^{3}$, Arturo Alvarez- \\ Buylla $^{4}$, and Jose Manuel Garcia-Verdugo ${ }^{1,2}$ \\ ${ }^{1}$ Laboratorio de Neurobiología Comparada, Instituto Cavanilles, Universidad de Valencia, 46980, \\ Valencia, Spain \\ ${ }^{2}$ Laboratorio de Morfología Celular, Centro de Investigación Príncipe Felipe, CIBERNED, 46013, \\ Valencia, Spain
}

${ }^{3}$ Department of Neurological Surgery, Barrow Neurological Institute, Phoenix, AZ 85013, USA

${ }^{4}$ Department of Neurological Surgery and Institute for Regeneration Medicine, University of California at San Francisco, San Francisco, CA 94143, USA

\section{Abstract}

Two neurogenic regions have been described in the adult brain, the lateral ventricle subventricular zone and the dentate gyrus subgranular zone. It has been suggested that neural stem cells also line the central canal of the adult spinal cord. Using transmission and scanning electron microscopy and immunostaining, we describe here the organization and cell types of the central canal epithelium in adult mice. The identity of dividing cells was determined by three-dimensional ultrastructural reconstructions of $\left[{ }^{3} \mathrm{H}\right]$ thymidine-labeled cells and confocal analysis of bromodeoxyuridine labeling. The most common cell type lining the central canal had two long motile $(9+2)$ cilia and was vimentin+, CD24+, FoxJ1+, Sox2+ and CD133+, but nestin- and glial fibrillary acidic protein (GFAP)-. These biciliated ependymal cells of the central canal (Ecc) resembled E2 cells of the lateral ventricles, but their basal bodies were different from that of E2 or E1 cells. Interestingly, we frequently found Ecc cells with two nuclei and four cilia, suggesting they are formed by incomplete cytokinesis or cell fusion. GFAP+ astrocytes with a single cilium and an orthogonally oriented centriole were also observed. The majority of dividing cells corresponded to biciliated Ecc cells. Central canal proliferation was most common during the active period of spinal cord growth. Pairs of labeled Ecc cells were observed within the central canal in adult mice 2.5 weeks post-labeling. Our work suggests that the vast majority of postnatal dividing cells in the central canal are Ecc cells and their proliferation is associated with the growth of the spinal cord.

\section{Keywords}

central canal; ultrastructure; ependyma; cilia

(C) 2012 Wiley-Liss, Inc.

Correspondence to: Arturo Alvarez-Buylla, Department of Neurological Surgery and Institute for Regeneration Medicine, University of California at San Francisco, San Francisco, CA 94143, USA. Phone: 415-514-2437, Fax: 415-514-2348,

abuylla@stemcell.ucsf.edu, Jose Manuel Garcia-Verdugo, Laboratorio de Neurobiología Comparada, Instituto Cavanilles de Biodiversidad y Biología Evolutiva, C/ Catedrático José Beltrán 2, 46980, Paterna (Valencia), Spain. Phone: +34 963543769, Fax: 963543670, j.manuel.garcia@uv.es.

\$Present address: Department of Clinical Neurosciences, Cambridge Centre for Brain Repair and Stem Cell Institute, University of Cambridge, Cambridge CB2 OPY, UK. 


\section{INTRODUCTION}

Neural stem cells persist in the walls of the lateral ventricles of adult rodents (Lois and Alvarez-Buylla, 1993) and humans (Sanai et al., 2004). It has been suggested that neural stem cells may persist in the walls of the ventricular system throughout the neuroaxis (Weiss et al., 1996). Proliferating cells have been observed in these periventricular regions including the spinal cord central canal (Horner et al., 2000; Martens et al., 2002). However, the epithelial cells that line the walls of the central canal in postnatal and adult life remain poorly understood.

Recent studies do not provide a consensus description of central canal cell types. Some authors differentiate ependymal cells and tanycytes (Mothe and Tator, 2005). Others define three subtypes: cuboidal ependymal, radial ependymal (in dorsal and ventral poles) and tanycytes (radial) (Meletis et al., 2008). Searching for a central canal equivalent to the subventricular zone (SVZ) of the lateral ventricles, Hamilton et al. defined a subependymal zone containing astrocytes, oligodendrocyte progenitors and neurons, all lacking contact to the canal lumen (Hamilton et al., 2009). Apart from ependymal cells and tanycytes, astrocytes in contact with the canal (Hamilton et al., 2009) and cerebrospinal fluid (CSF)contacting neurons (Marichal et al., 2009; Sabourin et al., 2009; Vigh et al., 2004) have been described.

Interestingly, a sub-population of these cells continues to divide during postnatal and adult life (Horner et al., 2000; Sabourin et al., 2009). Central canal proliferation increases with growth factor stimulation (Kojima and Tator, 2000; Martens et al., 2002) and after spinal cord injury (Beattie et al., 1997; Namiki and Tator, 1999). Of note, epithelial cells bordering the central canal respond to spinal cord injury increasing nestin expression (Shibuya et al., 2002) and some cells appear to migrate towards sites of injury to form glia (Meletis et al., 2008; Mothe and Tator, 2005). In addition, there is evidence that cells isolated from the adult spinal cord can self-renew and produce neurons, oligodendrocytes and astrocytes in culture (Weiss et al., 1996). Based on these observations, it has been postulated that a population of cells with neural stem cell properties resides in the central canal neuroepithelium of adult mammals (Hamilton et al., 2009; Martens et al., 2002; Meletis et al., 2008; Sabourin et al., 2009). The identity of putative spinal cord neural stem cells remains, however, uncertain.

It is widely accepted that a subpopulation of periventricular astrocytes, called B1 cells, function as the primary progenitors for the generation of neurons (Capela and Temple, 2002; Chiasson et al., 1999; Doetsch et al., 1999; Mirzadeh et al., 2008) and oligodendrocytes (Gonzalez-Perez et al., 2009; Menn et al., 2006) in the forebrain SVZ. Multiciliated ependymal cells (E1 cells), which like B1 cells are derived from radial glia, appear to be postmitotic in juvenile and adult life (Spassky et al., 2005). Recent evidence suggests that a few multiciliated cells are generated in the aged brain, but these seem to be derived from the periventricular astrocytes (Luo et al., 2008). Finally, recently described biciliated E2 ependymal cells in the lateral ventricular walls are also not proliferative (Mirzadeh et al., 2008).

Martens et al. suggest that proliferating cells in the central canal are not the classical multiciliated ependymal cells, but cells homologous to SVZ B1 cells (Martens et al., 2002). However, using a genetic tracing approach, Meletis et al. report that following dorsal or lateral funiculus lesion, astrocytes and oligodendrocytes are generated from central canal ependymal cells (Meletis et al., 2008). Interestingly, the ependymal cells they identified were not the classical multiciliated ependymal (E1) cells, but three subpopulations of cells (cuboidal ependymal, radial ependymal and tanycytes) with one to three cilia. Based on the 
accumulation of proliferating cells in the dorsal region, dorsal ependymal cells have also been suggested as the potential stem cells (Hamilton et al., 2009). Another study identified neural stem cells as dorsally located glial fibrillary acidic protein (GFAP)+ cells using GFAP-green fluorescent protein (GFP) transgenic mice (Sabourin et al., 2009). In order to identify the adult spinal cord periventricular stem cells, it is crucial to better characterize the epithelium lining the central canal using three-dimensional reconstruction to establish the proliferative population.

Here we identified a population of proliferating cells and their progeny with transmission electron microscopy (TEM) three-dimensional reconstructions of $\left[{ }^{3} \mathrm{H}\right]$ thymidine-labeled cells. The most common proliferating cell type in the epithelium lining the spinal cord central canal had two long motile cilia, each associated to a large basal body. We also found several interesting, previously undescribed subpopulations in the epithelium of the central canal: binucleated cells with four cilia, and cells similar to biciliated cells, but with one or three cilia and associated large basal bodies. Some of these uniciliated cells were also labeled by $\left[{ }^{3} \mathrm{H}\right]$ thymidine. We also observed CSF-contacting neurons and some GFAP+ astrocytes with a single cilium, classical basal body, and an orthogonally oriented centriole, similar to B1 cells in the SVZ. The postnatal timing of higher proliferation together with the distribution of pairs of $\left[{ }^{3} \mathrm{H}\right]$ thymidine- or bromodeoxyuridine (BrdU)-labeled cells at different time points after injection suggested that proliferation of biciliated cells contributed to central canal length extension during spinal cord growth.

\section{MATERIALS AND METHODS}

\section{Animals}

CD1-mice (1-13 weeks old) were used in all experiments. Before perfusion, mice were deeply anesthetized with Ketamine/Xylazine injected intraperitoneally (i.p.). The maintenance and use of animals was in accordance with the European Communities Council (86/609/EEC) guidelines, as well as in accordance with guidelines of the UCSF laboratory animal care and use committee.

\section{BrdU and $\left[{ }^{3} \mathrm{H}\right]$ thymidine injection}

To identify proliferating cells by TEM, adult mice received one i.p. injection of $\left[{ }^{3} \mathrm{H}\right]$ thymidine $(1.67 \mu \mathrm{l} / \mathrm{g}$ body weight, specific activity $5 \mathrm{Ci} / \mathrm{mmol}$, Amersham Biosciences, Uppsala, Sweden) or BrdU (50 mg/kg body weight) and were perfused 1 hour after injection $(\mathrm{n}=5$ for each treatment). To detect label retaining cells, we injected thymidine analogues as above, but perfused the animals after a 2.5 weeks survival period ( $\mathrm{n}=4$ for $\mathrm{BrdU}$ ). To label more label retaining cells for TEM analysis, another group of mice was injected with $\left[{ }^{3} \mathrm{H}\right]$ thymidine or BrdU every 12 hours over a one week period, followed by a 2.5 weeks survival period ( $\mathrm{n}=4$ for $\mathrm{BrdU}$ and $\mathrm{n}=2$ for $\left[{ }^{3} \mathrm{H}\right]$ thymidine).

\section{Transmission electron microscopy and autoradiography}

Mice $(\mathrm{n}=6)$ were perfused with $0.9 \%$ saline, followed by $2 \%$ paraformaldehyde (PFA) and $2.5 \%$ glutaraldehyde (EMS). Spinal cords were postfixed overnight in the same fixative and then microdissected into cervical, thoracic and lumbar regions. Spinal cord pieces were cut transversally or longitudinally at $200 \mu \mathrm{m}$, post-fixed in $2 \%$ osmium for 2 hours, rinsed, dehydrated, and embedded in araldite (Durcupan; Fluka, Buchs, Switzerland). Semithin sections $(1.5 \mu \mathrm{m})$ were cut with a diamond knife and stained with toluidine blue. To identify individual cell types, ultrathin sections $(60-70 \mathrm{~nm})$ were cut with a diamond knife, stained with lead citrate, and examined under a transmission electron microscope (Tecnai Spirit G2, FEI, Netherlands) using a digital camera (Morada, Soft Imaging System, Olympus, Japan). 
Adjustment of brightness and contrast of the pictures, if needed, was performed with Adobe Photoshop (Adobe Systems, San Jose, CA).

Three-dimensional reconstruction of three spinal cord segments (cervical, thoracic and lumbar) was performed as previously described (Doetsch et al., 1997). We photographed every third section for cell composition studies or every section for cilia reconstructions. Digital electron photomicrographs from each level were mounted with Adobe Photoshop and printed. The different cells forming the central canal were traced and numbered on printed reconstructions to facilitate following cell profiles on consecutive photomicrographs.

Autoradiograms were performed on transverse and longitudinal semithin sections (1.5 $\mu \mathrm{m})$ as described (Doetsch et al., 1997). Consecutive sections showing labeled cells were selected under a light microscope (Nikon, Eclipse), re-embedded and ultrathin-sectioned for TEM reconstruction as described (Alfaro-Cervello et al., 2010). $\left[{ }^{3} \mathrm{H}\right]$ thymidine-labeled cells were extremely rare 1 hour after injection: In 48-144 transverse semithin sections studied per animal (608 total sections), separated by $7.5 \mu \mathrm{m}$, a total of 19264 nuclei close to the central canal were observed. Of these only 10 were labeled with $\left[{ }^{3} \mathrm{H}\right]$ thymidine. Many of these cells were not in contact with the lumen when analyzed under TEM. To analyze a larger number of central canal cells, we also studied longitudinal semithin sections, which allowed us to analyze a total of 14 central canal contacting cells labeled with $\left[{ }^{3} \mathrm{H}\right]$ thymidine ( 2 transversally and 12 longitudinally cut). To study label retaining cells (multiple injections followed by 2.5 weeks survival), 192 transverse semithin sections were analyzed per animal (384 total sections), separated by $7.5 \mu \mathrm{m} .12752$ central canal nuclei were studied; 53 of these nuclei were labeled with $\left[{ }^{3} \mathrm{H}\right]$ thymidine, and 21 cells where analyzed.

\section{Scanning electron microscopy}

Adult mice $(\mathrm{n}=4)$ were perfused with $0.9 \%$ saline and the spinal cords were removed, microdissected into cervical, thoracic and lumbar regions, and then each segment was cut longitudinally in the mid-sagittal plane along the central canal, exposing its ependymal surface. This tissue was immersion-fixed in 2\% PFA and 2.5\% glutaraldehyde for 1 hour. Tissue blocks were then postfixed in $1 \%$ osmium for 1 hour, dehydrated, critical point dried, sputter-coated, and analyzed under the scanning electron microscope (S-4100, Hitachi, Japan).

\section{Immunocytochemistry}

Animals were perfused with $0.9 \%$ saline followed by $4 \%$ PFA. The spinal cords were postfixed overnight in the same fixative, and then microdissected into cervical, thoracic and lumbar blocks. $50 \mu \mathrm{m}$ sections were cut on a vibratome (Leica).

Primary and secondary antibodies were incubated in phosphate-buffered saline (PBS; $\mathrm{pH}$ 7.4) with $0.2 \% \mathrm{Tx} \mathrm{X}-100,5 \%$ normal goat serum and $8 \% \mathrm{BSA}$ for 24 hours at $4^{\circ} \mathrm{C}$. Primary antibodies used are listed in Table 1. Sections for permanent peroxidase staining were incubated for 1 hour in secondary biotinylated antibodies followed by incubation in $\mathrm{ABC}$ Elite complex (Vector, Burlingame, CA, USA). The sections were washed, and antibody staining was revealed with $0.05 \%$ diaminobenzidine and $0.01 \%$ hydrogen peroxide. For fluorescent immunostaining, secondary antibodies conjugated to Alexa Fluor dyes (goat polyclonal, 1:500, Molecular Probes) were used. Confocal images were taken on a Leica SP5 microscope and images were analyzed with the Leica Confocal Software and mounted with Adobe Photoshop.

For pre- and post- embedding stainings, animals were perfused with $0.9 \%$ saline followed by 4\% PFA and $0.5 \%$ glutaraldehyde. GFAP immunostaining on semithin sections was performed as described (Crespo et al., 2003). Pre-embedding immunogold staining was 
performed incubating in primary antibodyies (1:100 for anti-Sox 2 and anti-GFAP; 1:200 for anti-GFP) and in the appropriate colloidal gold conjugated secondary antibodies (1:50; UltraSmall; Aurion) as described (Alfaro-Cervello et al., 2010).

\section{Whole mount dissection, immunostaining and microscopy}

Spinal cords were freshly-dissected in $37^{\circ} \mathrm{C}$ Leibovitz media. The spinal cord was longitudinally bisected through the dorsal median fissure, and cut into cervical, thoracic and lumbar blocks. The dissected tissue blocks were fixed in 4\% PFA and $0.1 \%$ Tx X-100 overnight at $4{ }^{\circ} \mathrm{C}$. Primary and secondary antibodies were incubated in PBS with $0.5 \% \mathrm{Tx}$ $\mathrm{X}-100$ and $10 \%$ normal goat serum for 24 hours at $4^{\circ} \mathrm{C}$. After staining, the central canal epithelium was further dissected from the underlying parenchyma and thin portions of tissue were mounted on slides. Samples were alcohol dehydrated and covered with DPX mounting medium. Confocal images were taken on a Leica SP5 microscope.

\section{Antibody characterization}

BrdU is a thymidine analogue, capable of being incorporated into DNA in place of thymidine during DNA synthesis. Antibodies against BrdU recognize BrdU in single stranded DNA, BrdU coupled to a protein carrier or free BrdU (manufacturer's technical information). Nucleated cells which have had BrdU incorporated into their DNA in S-phase are detected. We did not find labeled cells on sections from mice that had not been injected with BrdU.

The anti-GFAP antibody detects a 51-kDa band from purified spinal cord (Debus et al., 1983). In crossed immunoelectrophoresis it shows one distinct precipitate (GFAP) with cow brain extract (manufacturer's technical information). In the central canal, this antibody strongly stained cells with the cellular morphology expected for astrocytes described in contact with the lateral ventricles (Doetsch et al., 1997).

Monoclonal anti-vimentin antibody recognizes an epitope of the cytoskeletal protein vimentin $(58 \mathrm{kDa})$ (manufacturer's technical information). Vimentin was expressed in mouse lateral ventricle ependymal cells in a morphology and pattern identical with previous reports (Mirzadeh et al., 2008).

The M1/69 antibody reacts with CD24 (Heat-Stable Antigen, HSA or HsAg), a variably glycosylated GPI-anchored membrane protein (manufacturer's technical information). Ependymal cells from the mouse lateral ventricles expressed CD24 on their membrane in a morphology and pattern similar to previous reports (Mirzadeh et al., 2008).

The phospho-histone $\mathrm{H} 3$ antibody is a mitosis marker that recognizes histone $\mathrm{H} 3$ when phosphorylated at Ser10. This antibody stains a single band of $17 \mathrm{kD}$ corresponding to phospho-histone $\mathrm{H} 3$ on Western blots from colcemid treated HeLa acid extract (manufacturer's technical information). Immunohistochemistry showed that the antibody labeled mitotic cells in areas with high cell proliferation such as the SVZ.

Mouse monoclonal anti-Ki67 detects the Ki67 nuclear antigen, expressed on all proliferating cells during late G1, S, M and G2 phases of the cell cycle (Kee et al., 2002). This antibody exhibited nuclear immunoreactivity in highly proliferative regions such as the SVZ.

Anti $\mathrm{Y}$-tubulin antibodies detect a band of $48 \mathrm{kDa}$ in Western blot (manufacturer's technical information). $Y$-tubulin is expressed within the microtubule organizing centers or centrosomes in eukaryotic cells (Oakley, 1992). Y-tubulin is also localized in ependymal basal bodies from the mouse lateral ventricles (Mirzadeh et al., 2008). 
Anti $\beta$-catenin (Sigma) reacts with a $94 \mathrm{kDa}$ protein in extracts of Madin-Darby Bovine Kidney (MDBK) cultured cell line (manufacturer's technical information), and anti $\beta$-catenin (BD) recognizes a $92 \mathrm{kDa}$ protein on HeLa cell lysate in Western blot (manufacturer's technical information). The $\beta$-catenin immunoreactivity in the central canal surface was similar to that reported previously in the lateral ventricle whole mount stainings (Mirzadeh et al., 2008).

The specificity of the anti-GFP antibody has been analyzed by Western blot and immunohistochemistry using transgenic mice expressing the GFP gene product (manufacturer's information).

Anti-NeuN recognizes 2 to 3 bands in the 46-48 $\mathrm{kDa}$ range and another band at approximately $66 \mathrm{kD}$ in Western blots of the rat brain. The antigen is expressed by mature neurons in the adult mouse dentate gyrus (Brandt et al., 2003). Mouse spinal cord motoneurons were strongly labeled with this antibody.

Doublecortin (DCX) was detected with a rabbit polyclonal anti-DCX antibody raised against a 16-amino acid synthetic peptide. According to the manufacturer, when tested by Western blot, this antiserum detects a 40-45-kDa band in mouse brain lysates. Migrating neuroblasts in the mouse SVZ were stained with this antibody as described (Brown et al., 2003).

The nestin antibody was described to label neuroepithelial progenitor cells by immunohistochemical analysis (Hockfield and McKay, 1985; Lendahl et al., 1990). In Western Blot, the antibody recognizes a band of 200-220 kDa in newborn rat or mouse cell extracts (manufacturer's technical information). This antibody gave us a staining pattern as reported previously in neural precursor cells in the mouse SVZ (Gritti et al., 1996).

Sox 2 is an HMG box transcription factor, which is expressed in neural progenitor cells (Komitova and Eriksson, 2004). On western blots of whole cell or nuclear extracts, the antibody recognizes a $34 \mathrm{kDa}$ band corresponding to Sox 2 that is not observed in cytosolic extracts (manufacturer's technical information). This antibody recognized cell nuclei in the mouse SVZ as described (Komitova and Eriksson, 2004).

The 13A4 monoclonal antibody recognizes the extracellular domain of mouse Prominin-1/ CD133, a 115-120 kDa pentaspan transmembrane (5-TM) domain glycoprotein. Prominin-1 is expressed in the apical membrane of embryonic radial glial cells (Weigmann et al., 1997). Both ependymal cells and GFAP+ stem cells from the lateral ventricles were shown to express CD133 (Mirzadeh et al., 2008).

\section{Ependymal flow movies}

Whole mounts of the central canal were freshly dissected and placed in $37^{\circ} \mathrm{C}$ Leibovitz media under a fluorescent stereomicroscope and fluorescent microbeads $(2 \mu \mathrm{m})$ were deposited onto the central canal surface as described (Mirzadeh et al., 2010). Flow of microbeads was recorded using a Retiga 2000R high speed digital camera plugged into OpenLab imaging software (Improvision), with an acquisition rate of 10 frames per second.

\section{Cell counting}

To analyze the position of BrdU+ cells in the central canal, we used a radial template dividing the canal into 16 sectors. We photographed sections separated by $\sim 250 \mu \mathrm{m}$ (7-19 sections per region per animal) using a $100 \times$ immersion objective. The template was superimposed on the central canal image with the center of the template in the canal center. We defined 8 regions from dorsal to ventral as follows: dorsal, dorsolateral, lateral 1 to 4 , 
ventrolateral and ventral. Statistical analyses were performed with Student's t-test or ANOVA followed by Tukey post-hoc test, with results considered significant at $P<0.05$.

\section{RESULTS}

We first characterized the different cell types in contact with the central canal of 2-3 month old mice. Interestingly, characteristic multiciliated ependymal cells with large numbers of cilia were not observed. We have used multiple techniques to look for classical ependymal cells with large bundles of cilia (Mirzadeh et al., 2008; Spassky et al., 2005), including scanning electron microscopy (SEM) and immunocytochemistry of whole mount open canal preparations, but have not observed these cells in adult mice. Instead the most common cell type in this epithelium had two cilia with some similarities (see below) to E2 cells recently described in the lateral ventricular wall (Mirzadeh et al., 2008). We also observed smaller subpopulations of cells with 1, 3 and 4 cilia. All these cells were highly polarized, had lipid droplets and other characteristic ependymal features (see below) and we will refer to them as central canal ependymal (Ecc) cells. In addition, we found smaller populations of cells in contact with the central canal that had characteristics of astrocytes or neurons. Semithin and TEM sections also showed microglia next to the epithelial layer.

\section{Central canal ependymal (Ecc) cells}

In toluidine blue-stained semithin sections, cells around the central canal were organized as a pseudostratified epithelium. In the cervical spinal cord, the central canal was typically round or oval. At thoracic and lumbar levels, the central canal was usually obliterated (collapsed) and showed a dorsoventrally elongated shape (Fig. 1A-B). However, the cell types observed and their general organization was similar at cervical, thoracic and lumbar levels of the spinal cord. The region around the central canal was highly vascularized, with numerous vessels running longitudinally next to the epithelium. Central canal cells frequently had radial expansions, some of which made contacts with blood vessels (Fig. 1C).

We next studied the central canal by SEM and TEM. SEM of spinal cord, fractured longitudinally or transversely, demonstrated that many of the cells surrounding the central canal had long radial processes (Fig. 1D). Ecc cells' radial processes were also identified by TEM. However, a subpopulation of cells on the lateral walls of the central canal, reconstructed in serial ultrathin sections, did not have these radial processes. These more globular cells were also observed under SEM (Fig. 1D). Ecc cells under TEM had a pseudostratified organization (Fig. 1E) and electron-dense cytoplasm rich in intermediate filaments (Fig. 1F). These cells had a characteristic horse-shoe shaped Golgi apparatus polarized with the cis-side towards the lumen (Fig. 1G), numerous dark mitochondria throughout the basal and apical cytoplasm, and apically located lipid droplets. The rough endoplasmic reticulum (RER) was small with few free ribosomes. Nuclei were mostly located in the apical row of the pseudostratified epithelium. The chromatin was condensed in small clumps, with 3 to 4 nucleoli associated with the nuclear envelope. Long zonulae adherens junctions with a beaded appearance comprised of electron-dense clumps alternating with thin tightly apposed electron-dense membranes were observed between adjoining cells (Fig. 1H). Intercellular spaces and deep interdigitations were also observed on the apical surface of Ecc cells. An extended network of basal lamina, similar to that observed in the walls of the lateral ventricles (Mercier et al., 2002), was observed between Ecc cells and on the basal side of these cells (Fig. 1I), as well as on their expansions in contact with blood vessels' basal lamina (Fig. 1J). Interestingly, Ecc cells frequently contacted neurons surrounding the central canal basally (not shown).

On the most dorsal and ventral tips of the central canal, ependymal cells had a characteristic morphology. They showed a very long radial expansion containing intermediate filaments 
running towards the pial surface of the spinal cord. Dorsally located radial processes from Ecc cells were particularly long. However, we do not know if these cells reached the pial surface. These radial expansions were partly isolated from adjacent structures by astrocytic expansions. These cells always presented a very narrow contact with the central canal, had a very large Golgi apparatus, and an elongated nucleus that was invaginated, with its long axis parallel to the dorsoventral axis of the canal. In addition, we occasionally observed displaced Ecc cells (not shown). These cells did not contact the lumen, but displayed morphological characteristics of ependyma: similar cytoplasm, organelles, basal lamina, junction complexes, microvilli and internalized cilia and basal bodies.

In summary, most cells contacting the central canal showed similar features (Ecc cells): electron-dense cytoplasm rich in intermediate filaments, a nucleus with small chromatin clumps, and a radial expansion. The ultrastructural properties of cells forming the central canal in adult mice are summarized in Table 2. Next we performed a comprehensive analysis of the apical surface of Ecc cells using serial ultrathin section $(60-70 \mathrm{~nm})$ reconstructions.

\section{Ciliary structure of Ecc cells}

Serial sections and three-dimensional reconstructions of the apical surface of Ecc cells allowed us to study their ciliary structure. Most Ecc cells had 2 cilia associated to two unique large electron-dense basal bodies (Fig. 1K). The cilia of biciliated cells were long (7$9 \mu \mathrm{m}$ ) and had a 9+2 microtubule axoneme structure (Fig. 2A). Interestingly, the proximal segment of the cilium was invaginated, with specialized electron-dense apposing membranes close to the structures anchoring the basal body. The basal body had a unique structure different from that associated with cilia of E1, E2 or B1 cells or other cell types previously described around the ventricular system (Doetsch et al., 2002; Mirzadeh et al., 2008; Spassky et al., 2005). Ecc basal bodies were not associated to a daughter centriole, as observed with the primary cilium in B1 cells of the lateral ventricle (Doetsch et al., 2002; Mirzadeh et al., 2008). Instead, in these cells it appeared that both centrioles were associated to complex pericentriolar electron-dense particles with a lobular configuration similar to that observed in E2 cells of the lateral ventricles (Mirzadeh et al., 2008). The pericentriolar material makes Ecc basal bodies much larger than E1 cell basal bodies, but smaller than those in E2 cells (Mirzadeh et al., 2008). In tangentially cut sections (i.e. en face - cut parallel to the luminal surface), the complex and electron-dense material associated to Ecc basal bodies appeared to be organized into multiple (up to six) radial spikes (Fig. 2B). However, the electron-dense pericentriolar material in Ecc cells basal bodies was not always compact. In some cells it appeared fragmented (see Fig. 8P and OT), possibly associated with transitional forms in the assembly or disassembly of these structures. Ecc basal bodies were also associated to long striated ciliary roots. These ciliary roots were closely linked to mitochondria.

En face TEM of the central canal confirmed that most Ecc cells had 2 cilia associated with specialized basal bodies as described above. Among neighboring Ecc cells, the basal bodies were usually oriented in the same direction with similar distances between basal bodies of adjacent cells (Fig. 2D). To analyze greater portions of ependymal surface, we performed whole mount immunostaining for $\beta$-catenin, to delineate cell borders, and $\gamma$-tubulin, to label the basal bodies. En face imaging of the central canal surface with confocal microscopy confirmed that most of the cells on the ventricular surface had two long cilia with large donut-shaped basal bodies (Fig. 2E). Quantification of the number of cilia on Ecc cells showed that most contained two basal bodies $(77,88 \pm 1,54 \%) .11,99 \pm 1,61 \%$ had one cilium, $4,11 \pm 1,46 \%$ three cilia and $6,02 \pm 0,95 \%$ four cilia. SEM also confirmed these observations showing that most cells in contact with the central canal had two long cilia (Fig. 2C). 
We then reconstructed the apical surface of 61 Ecc cells using TEM. For this, 60-70 nm ultrathin sections of the entire apical surface were serially collected in slot grids. Every third section was studied at the TEM. This analysis confirmed that the majority $(81,97 \%)$ of Ecc cells had 2 cilia and associated complex basal bodies with no daughter centrioles. A small population of Ecc cells $(6,56 \%)$ had only one cilium. These cells had associated to their large basal body a single $9+2$ cilium similar to those observed in the biciliated cells. The basal body and cilia of these uniciliated Ecc cells was very different than that of uniciliated B1 cells of the lateral ventricular walls (Doetsch et al., 2002; Mirzadeh et al., 2008) or astrocytes around the central canal (see below). Essentially, the ultrastructure of these uniciliated cells was the same as described above for biciliated Ecc cells. A smaller proportion (4,92\%) of the Ecc cells had 3 cilia and another (4,92\%) had 4 cilia. In a small percentage of cells $(1,64 \%)$ we could find no cilia in the reconstructed apical processes. In summary, Ecc cells had a unique apical structure. Most of them had 2 cilia, but subpopulations of cells also had 1, 3 or 4 cilia.

Interestingly, we noticed that cells with 4 cilia were generally larger in size compared to other Ecc cells, with a wider apical surface and more abundant cytoplasm. These cells had 4 complex basal bodies similar to those in biciliated cells and lacked daughter centrioles. Using serial ultrathin sections of 6 cells with 4 cilia, in which the entire cell was contained within our serial reconstruction, we made an unexpected observation: all six Ecc cells with 4 cilia had two nuclei (Fig. 2F-G). Using the serial section series, we confirmed that the two nuclei were in fact distinct structures and not simply corresponding to a single bi-lobulated nucleus. In some binucleated cells, both nuclei were observed in the same epithelium row, while in other cases nuclei appeared in different rows at different distances from the central canal lumen. Of note, one of the two nuclei appeared to have a higher concentration of condensed chromatin compared to the other. Confocal reconstructions of immunostained whole mounts confirmed that cells with 4 basal bodies had 2 nuclei (Fig. $2 \mathrm{H}$ ). These binucleated cells were not rare, and were found in all studied spinal cord regions along the rostrocaudal and dorsoventral axes. To our knowledge, this is the first description of binucleated ependymal cells.

A recent study in zebrafish showed direct evidence for cilia-driven CSF flow in the central canal (Kramer-Zucker et al., 2005). Interestingly, this study showed that central canal cilia in zebrafish have a (9+0) axoneme. Based on high-speed videomicroscopy, the authors suggested that these cilia move with a rotatory pattern, similar to nodal $(9+0)$ cilia in the early embryo (Nonaka et al., 1998). Early studies of the central canal ependyma in mammals provided indirect evidence for CSF flow: following intraventricular dye injection, the central canal was analyzed at various time points to determine the luminal passage of dye (Bradbury and Lathem, 1965). Direct evidence based on dynamic imaging, however, is lacking in mammals. Based on the 9+2 microtubule organization of Ecc cilia and the abundant mitochondria in their apical cytoplasm, we hypothesized that these cilia were motile. To test their motility, we microdissected spinal cords longitudinally to expose the central canal surface, onto which we deposited fluorescent beads $(2 \mu \mathrm{m})$ using a micropipette (Mirzadeh et al., 2008). After allowing the preparation to stabilize, the beads located along the central canal, and only those along the central canal moved longitudinally (Suppl. Movie). Occasionally, we observed beads that became attached to the motile cilia and moved rapidly back-and-forth, reflecting the motion of the cilia themselves. This back-and-forth motion was in contrast to the rotatory motion observed in zebrafish central canal cilia (KramerZucker et al., 2005), and is consistent with the normally whip-like beating of (9+2) cilia.

\section{Astrocytes and neurons in contact with the central canal}

In addition to Ecc cells, our TEM analysis revealed subpopulations of astrocytes and neurons in contact with the central canal (Fig. 3 and Table 2). Central canal contacting 
astrocytes (Acc) were readily distinguished from Ecc cells based on their ultrastructural properties. They had light cytoplasm and thick bundles of intermediate filaments. In contrast to intermediate filaments in Ecc, which had a clumped organization, intermediate filaments in Acc cells were homogenously distributed within the cytoplasm. Furthermore, Acc cells did not have lipid droplets, they had large and round mitochondria, a sparse Golgi apparatus, and nuclei with irregular borders and frequent invaginations that contained lax chromatin in large clumps and 1 to 2 nucleoli. Acc cells contacted the central canal through a thin process and had a primary cilium with a typical basal body and associated daughter centriole (Fig. 3A). Acc cells were observed in the lateral as well as dorsal and ventral regions around the central canal.

As previously described (Marichal et al., 2009; Vigh et al., 2004), we observed many thin neuronal processes containing parallel bundles of microtubules (Fig. 3F-G) intercalated between Ecc cells at cervical, thoracic, and lumbar levels of the spinal cord. Interestingly, the processes of central canal contacting neurons (Ncc) ended inside the central canal lumen with a globular expansion containing numerous pleomorphic vesicles. These globular expansions, which were observed at all dorsoventral locations studied, were rich in mitochondria (Fig. 3G). The cytoplasm of these neurons was less electron-dense than Ecc cells and contained abundant RER, free ribosomes and vesicles, and no intermediate filaments or lipid droplets. Golgi and mitochondria in Ncc cells were elongated as in Ecc cells. The nucleus was round with small chromatin clumps associated to the nuclear envelope and contained 1 to 2 nucleoli. Ncc cells received axo-somatic synaptic contacts (Fig. 3H), and expressed the immature neuronal marker DCX (Fig. 3L-M), further confirming their neuronal identity, but not NeuN. In their basal cytoplasm, Ncc cells contained a single cilium with an orthogonally oriented centriole (Fig. 3J-K).

Finally, we found a rare subpopulation of basally located cell bodies (beneath the ependymal layer) with typical astrocytic ultrastructure, including bundled intermediate filaments and light cytoplasm, which had a thin process contacting the central canal. Interestingly, rather than extending the typical primary cilium from the apical surface of this process, like Acc cells, these cells extended $2(9+2)$ cilia and large basal bodies with no evidence of a centriole. We only encountered two examples of these cells, indicating that they are extremely rare.

\section{Molecular markers}

To further characterize the different types of cells present in the epithelium surrounding the central canal, we performed immunocytochemistry in $50 \mu \mathrm{m}$ vibratome sections and imaged with confocal microscopy. The intermediate filament vimentin was observed in the cytoplasm of most cell bodies in the central canal epithelium and in some of the radial processes (Fig. 4A). In contrast, only a subpopulation of the cell bodies surrounding the central canal expressed high levels of GFAP $(8,7 \pm 1,4 \%$ ) (Fig. 4B). A subpopulation of cells strongly expressed GFAP and vimentin in long processes that reached quite a distance from the central canal (Fig. 4C). In fact, most of the strongly GFAP+ cells were also vimentin+ and these cells were preferentially located in the lateral and ventral regions surrounding the central canal, while GFAP+ cells not expressing vimentin tended to accumulate wedged in the dorsal region. In addition, light GFAP staining was observed in most of the cells surrounding the central canal. This pattern of staining for intermediate filaments was similar at all rostrocaudal levels of the spinal cord studied (cervical, thoracic and lumbar).

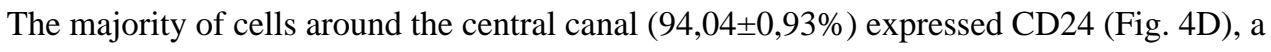
cell surface marker of differentiated ependymal cells (Mirzadeh et al., 2008). CD24 was highly expressed in the apical surface, with lower level expression around the perimeter of cell bodies. A small subpopulation of CD24- cells was present in the dorsal wedge of the 
central canal, coinciding with the region of GFAP+/vimentin- cells (see above); consistently, about half $(45,1 \pm 14 \%)$ of all CD24- cells were GFAP+ (Fig. 4F).

Nestin, an intermediate filament typically found in neural precursor cells, was expressed predominantly in the dorsal and ventral regions of the central canal. Labeled cells exhibited very long radial processes, especially at the dorsal region (Fig 4G). Frequently, nestin+ cells also expressed GFAP (Fig. 4I).

FoxJ1 is considered a marker for ciliated epithelia and the ependymal cell lineage (Huang et al., 2003; Meletis et al., 2008). However, a recent report indicates that a subpopulation of FoxJ1 expressing cells in the walls of the lateral ventricle correspond to astrocytes (Jacquet et al., 2009). The expression of FoxJ1 was studied in mice expressing Cre under the FoxJ1 promoter (Zhang et al., 2007) crossed to Z/EG mice, which express EGFP after Cre recombination. In the FoxJ1::Cre;Z/EG mice, $20 \%$ of central canal epithelial cells were GFP+, with no labeled cells found in the parenchyma. FoxJ1+ cells also expressed vimentin and CD24 (Fig. 4L and 4O). Using whole mount staining, we observed that GFP+ cells had two complex basal bodies characteristic of Ecc cells (Fig. 5A-C). Furthermore, we used preembedding immunogold staining to confirm that FoxJ1+ cells corresponded to Ecc cells (Fig. 5D-G).

To correlate the above marker expression with the different cell types identified by TEM, 50 $\mu \mathrm{m}$ vibratome sections were immunostained, embedded in plastic, and sectioned at $1.5 \mu \mathrm{m}$ intervals. Selected sections were re-sectioned at $60-70 \mathrm{~nm}$ for TEM. This pre-embedding immunostaining analysis revealed that vimentin+ cells had two large electron-dense basal bodies, two $(9+2)$ cilia, and a radial process in contact with basal lamina and blood vessels (Fig. 5H-J). These are characteristics of Ecc cells described above. GFAP-labeled cells, in contrast, had light cytoplasm and Acc ultrastructure. Some GFAP+ cells displayed a single cilium with an orthogonally oriented centriole (Fig. 3C-E). Semithin immunostaining confirmed that a subpopulation of subependymal GFAP+ cells contacted the canal lumen through thin processes (Fig. 3B). Light GFAP immunogold staining was also observed in Ecc cells, consistent with the light microscopy analysis (see above).

We next performed pre-embedding immunostaining for additional glial and neural stem cell markers previously detected in the central canal, in order to correlate them with the different cell types identified. Electron microscopy analysis of nestin labeled cells showed that they contained a single cilium with a centriole, characteristics of the GFAP+ astrocytes that contact the central canal as described above (Fig. 5K-L). Prominin-1/CD133, a surface marker previously detected both in ependymal cells and astrocytes from the lateral ventricles (Mirzadeh et al., 2008), was detected on the entire surface of the central canal, as previously described (Meletis et al., 2008). Pre-embedding immunostaining confirmed that Ecc cells expressed CD133 on their surface (Fig. 5M-O). Because central canal astrocytes are less frequent and contact the lumen through a thin process with a narrow surface, and CD133 staining was widespread on the canal surface, it was not possible to clearly identify the presence of CD133 in astrocytes. As previously reported in the mouse (Meletis et al., 2008) and human (Dromard et al., 2008) spinal cord, we detected high expression of the transcription factor Sox 2 in cells contacting the central canal. Sox 2 was present in the nuclei of Ecc and Acc cells (Fig. 5P-Q).

\section{In situ proliferation and newly generated cells}

Proliferation around the central canal was studied using Ki67 and BrdU immunostaining and $\left[{ }^{3} \mathrm{H}\right]$ thymidine autoradiography. In accordance with previous studies (Horner et al., 2000), we found that proliferation around the central canal was extremely rare. Sporadic Ki67 (one 
labeled cell in about six $50 \mu \mathrm{m}$ sections) or rare phospho-histone H3 positive nuclei were observed (not shown).

One cell was caught in mitosis and was studied in detail in serial sections by TEM (not shown). The chromatin had condensed into typical aggregates seen in mitotic cells without a nuclear envelope. Part of the centrosome was observed basally. Similar to Ecc cells, the mitotic cell was in direct contact with the canal, and showed contact with basal lamina. Apically we observed two basal bodies with associated electron-dense particles, suggesting a dynamic rearrangement of these particles to or from the basal bodies.

To quantitatively assess the proliferation of central canal cells in the adult mouse, we injected BrdU either 1 hour prior to sacrifice, to label actively proliferating cells, or 2.5 weeks prior to sacrifice, to label newly generated cells (Fig. 6A). We found no difference in the distribution along the rostrocaudal axis of either proliferating cells (1 hour survival) or newly generated cells ( 2.5 weeks survival) around the central canal (Fig. 6B-C). As it is possible that different cell densities along the central canal could affect the number of cells detected in each region, we analyzed the proportion of labeled cells from the total central canal cells, and found no difference in proliferation along the rostrocaudal central canal (not shown).

We also compared the number of labeled cells within the central canal epithelium to labeled cells in the whole spinal cord, including the parenchyma, at 1 hour and 2.5 weeks postinjection. There were no significant differences in the percentage of labeled cells in the central canal epithelium at 1 hour vs. 2.5 weeks post-injection, with $4.31 \% \pm 0.61$ of BrdUlabeled cells within the central canal epithelium at 1 hour and $5.52 \% \pm 2.38$ at 2.5 weeks (Fig. 6D). We observed a significant increase in the number of labeled pairs of cells at 2.5 weeks vs. 1 hour in the central canal $(7.82 \% \pm 4.09$ at 1 hour and $86.14 \% \pm 8.51$ at 2.5 weeks) (Fig. $6 \mathrm{E})$. In contrast, in the spinal cord parenchyma, only a small increase in pairs of BrdU labeled cells was observed (3.66 $\pm 1.16 \%$ at 1 hour and $6.29 \pm 2.24 \%$ at 2.5 weeks). This suggests that daughter cells around the central canal tend to maintain their position in the epithelium after division, while daughter cells in the parenchyma move away from each other after division. Of note, the number of labeled cells did not significantly increase between 1 hour and 2.5 weeks in either the central canal or in the parenchyma (Fig. 6F-G). This may be due to the dilution of BrdU or to cell death.

To investigate the location of BrdU-labeled cells along the dorsoventral axis, we analyzed their distribution using a template of eight dorsoventral radial sectors as described above (Fig. 6H-K). Labeled cells were observed all around the central canal, but with increased frequency in the dorsal and ventral sectors compared to lateral sectors. This difference was maintained at both survival time points, consistent with cells not migrating or dispersing after division.

\section{Identification of proliferating and newly generated central canal cells}

Double immunostaining for an ependymal marker, either vimentin or CD24, and BrdU (1 hour survival post-injection) suggested that ependymal cells were proliferating in the central canal. In cross sections of the spinal cord, $80 \%$ of BrdU-labeled cells in the central canal epithelium expressed CD24, and 20\% expressed GFAP (Fig. 7A-C). This suggested that Ecc cells were incorporating BrdU. Consistently, whole-mount immunostaining showed BrdU+ cells with two donut-shaped basal bodies at their apical surface ( 2 hours postinjection) (Fig. 7G-I). To label daughter cells, we performed similar immunostaining in samples from mice that received 14 injections of BrdU (12 hours between injections) with a 2.5 weeks survival period after the last injection (Fig. 6A). Double immunofluorescence showed that $96 \%$ of BrdU+ cells in the central canal epithelium expressed CD24 (Fig. 7D). 
Approximately $14 \%$ of the BrdU+ cells expressed GFAP (Fig. 7E-F). Since cells in the central canal are so densely packed and because immunostaining in conjunction with light and confocal microscopy do not have the resolution to clearly distinguish apical structures, we used $\left[{ }^{3} \mathrm{H}\right]$ thymidine and autoradiography to clearly identify individual dividing central canal cells by TEM.

Dividing central canal cells are extremely rare in the adult. Therefore, we used autoradiograms on both transverse and longitudinal sections of the canal. This allowed us to study a larger sample of labeled cells. A single injection of $\left[{ }^{3} \mathrm{H}\right]$ thymidine was used with a survival of 1 hour. $\left[{ }^{3} \mathrm{H}\right]$ thymidine-labeled nuclei close to the central canal were identified in semithin sections (608 total sections analyzed across 5 mice). In order to consider a cell labeled, six or more autoradiographic grains needed to be present over the nucleus. More importantly, the nucleus had to be labeled in at least three consecutive serial $1.5 \mu \mathrm{m}$ sections. All contiguous semithin $1.5 \mu \mathrm{m}$ sections with labeled nuclei close to the central canal were re-embedded, thin sectioned $(60-70 \mathrm{~nm})$ and serially reconstructed for TEM analysis. Fourteen cells around the central canal were labeled according to the above mentioned criteria and contacted the canal lumen. All these cells had ultrastructural characteristics of Ecc cells, such as dark cytoplasm, often with a radial expansion. Most of them (11 of 14) contained two cilia with characteristic large, complex electron-dense basal bodies and 9+2 microtubular axonemes (Fig. 8A-B). Of these fourteen cells, one had only one cilium with a large basal body (Fig. 8C), and in two we could not find complete cilia, but instead several electron-dense particles, some of them resembling basal body pieces (Fig. 8D). Interestingly, 8 of the 14 labeled Ecc cells contained electron-dense particles in their apical cytoplasm, near the basal bodies (Fig. 8R). Sometimes these electron-dense particles were large and very similar to parts of the large basal bodies present in these cells, possibly indicating reassembly or disassembly of these structures. $\left[{ }^{3} \mathrm{H}\right]$ thymidine-labeled cells were found in both dorsal and ventral regions around the central canal and showed a similar morphology irrespective of their location. Labeled cells were closely associated to basal lamina around their basolateral cell membrane and around blood vessels. Frequently, labeled cells displaying morphological characteristics of microglia, electron-dense cytoplasm, abundant RER and lysosomes, and a nucleus with clumped chromatin, were detected close to the central canal (not shown). We did not find $\left[{ }^{3} \mathrm{H}\right]$ thymidine-labeled astrocytes or neurons in the central canal.

We next reconstructed for TEM analysis labeled cells around the central canal of mice that received 14 injections of $\left[{ }^{3} \mathrm{H}\right]$ thymidine (12 hours between injections) and a survival of 2.5 weeks after the last injection, comparable to the analysis of BrdU-labeled cells at the confocal microscope (Fig. 6A). Twenty-one $\left[{ }^{3} \mathrm{H}\right]$-labeled cells in contact with the canal were studied and all corresponded to Ecc cells with one or two large basal bodies. Of these 21, 12 cells had 2 cilia (Fig. 9A) and 7 cells displayed 1 cilium (Fig. 9B). Intriguingly, we found one labeled cell with 4 cilia and were unable to determine the number of cilia on the remaining labeled Ecc cell. In accordance with the BrdU study, most (15 of 21) of the $\left[{ }^{3} \mathrm{H}\right]-$ labeled cells studied were in pairs. We did not find labeled microglia, neurons or astrocytes in the central canal 2.5 weeks after $\left[{ }^{3} \mathrm{H}\right]$ thymidine injections. Interestingly, in contrast with mice that had the short ( 1 hour) survival, in mice that survived 2.5 weeks after $\left[{ }^{3} \mathrm{H}\right]$ thymidine labeling, we did not observe the electron-dense particles resembling parts of the basal body very frequently.

These results indicate that the majority of cells dividing around the central canal in young adult mice (2-3 month old) correspond to a specialized central canal form of ependymal cell (Ecc) with one or two cilia. Under normal conditions the majority of these cells appear to remain in the epithelium of the central canal after division suggesting that they are part of an extremely slow process of Ecc replacement or addition. 


\section{Proliferation of Ecc cells correlates with spinal cord growth}

As Ecc cells proliferate in situ and give rise to Ecc cells that remain in the central canal, we hypothesized that this proliferation could be associated to the tail-end of spinal cord growth. We determined the length of the spinal cord in mice between 1 and 13 weeks after birth. As expected based on the size of the animals, the spinal cord grows in length dramatically during this period $(2.54 \pm 0.03$ to $5.45 \pm 0.08 \mathrm{~cm})$, with the rate of growth decreasing as the animals reach their adult weight (Fig. 10A). We next investigated how the number of dividing cells around the central canal changes with age. Mice between 1 and 13 weeks of age received a single injection of BrdU and were killed 1 hour post-injection. The number of labeled cells around the central canal was studied in longitudinal sections (Fig. 10C-D). The number of proliferating central canal cells was highest in the youngest mice and decreased progressively with age. By 13 weeks, very few dividing cells were observed. The decrease in central canal proliferation closely paralleled the decrease in spinal cord growth (Fig. 10B).

\section{DISCUSSION}

In this study we used TEM serial reconstruction and immunocytochemistry to characterize the different cell types in contact with the central canal of young adult mice. We identified a specialized population of biciliated ependymal cells that exhibit cell division correlated to postnatal elongation of the spinal cord. These central canal ependymal (Ecc) cells typically had only 2 long cilia, but occasionally we found them with 1, 3 or 4 cilia. These cells had very large basal bodies, resembling those recently observed in E2 cells in the forebrain (Mirzadeh et al., 2008). Additionally, we found a subpopulation of central canal astrocytes (Acc) with a single primary cilium and neurons ( $\mathrm{Ncc}$ ) in contact with the central canal (Fig. 11). This cellular organization was maintained in the cervical, thoracic and lumbar spinal cord.

\section{Ecc cells are the major cell type of the central canal epithelium}

Our data suggest that Ecc cells are a subtype of ependymal cell, similar to forebrain E2 cells, because they have long motile cilia (9+2 axoneme structure) with large electron-dense basal bodies, microvilli, junction complexes, and ependymal lipid droplets (Peters et al., 1991). Ecc cells were the most common cell type found in the central canal and most of these cells were biciliated. Live imaging of whole mount preparations showed that cilia in Ecc cells were motile. Consistently, these cilia had 9+2 microtubule organization, similar to motile cilia of classical multiciliated ependymal cells (Bruni, 1998; Satir and Christensen, 2007). We did not find multiciliated ependymal cells in the central canal similar to those in the lateral ventricles. The small diameter of the mouse central canal may, in part, explain the absence of multiciliated ependymal cells. Other species with larger central canals, such as the rabbit, have ependymal cells with multiple cilia (Nakayama and Kohno, 1974).

Ecc cells in mice had a ciliary basal body that is very different to that of multiciliated ependymal cells, including E1 cells in the rodent forebrain (Mirzadeh et al., 2008; Spassky et al., 2005). The basal body of Ecc cells resembles that of E2 cells in the walls of the lateral ventricles (Mirzadeh et al., 2008). This suggests that Ecc cells of the central canal and E2 cells in walls of the lateral ventricle may share developmental and cellular specification programs. However, in contrast to Ecc cells, E2 in the walls of the lateral ventricles cells do not appear to divide in the adult brain (Mirzadeh et al., 2008). In addition, unlike some Ecc cells that had 1, 3 or 4 cilia, E2 cells have not been observed with only one cilium (Mirzadeh et al., 2008). 


\section{Ecc cells divide}

Our results show that proliferating cells in the walls of the central canal in adult mice are extremely rare, but most, if not all, of the proliferating cells under normal conditions correspond to Ecc cells. This is consistent with recent work indicating that ependymal cells with 1-3 cilia are proliferative in the central canal of adult mice (Meletis et al., 2008). The potential to proliferate and the number of cilia might be a key difference between Ecc and E1 multiciliated ependymal cells from the lateral ventricles. It is controversial whether ependymal cells with large number of cilia can divide. Some studies suggest that ciliated ependymal cells can divide in vitro and generate other glial cells (Chiasson et al., 1999; Laywell et al., 2000). Consistently, our results indicate that cells with one or two motile cilia can proliferate in vivo. However, in vivo evidence suggests that E1 ependymal cells in the walls of the lateral ventricle do not proliferate in the adult mouse (Mirzadeh et al., 2008; Spassky et al., 2005). Like other multiciliated epithelial populations in the body (Dirksen, 1971; Komatsu and Fujita, 1978; Otani et al., 1986; Rawlins et al., 2007), the large number of cilia in these cells may be incompatible with cell division. In multiciliated cells with bundles of up to 300 long motile cilia and associated small specialized basal bodies (Rawlins et al., 2007), the centrosomal organization for cell division may be irreversibly lost. It is therefore intriguing that biciliated Ecc cells enter the cell cycle and likely regenerate daughter centrioles during G2 and mitosis.

Interestingly, in our serial TEM reconstruction of $\left[{ }^{3} \mathrm{H}\right]$ thymidine-labeled and unlabeled Ecc cells, we could not detect centrioles, which usually are considered essential for normal cell division (Hinchcliffe et al., 2001; Khodjakov and Rieder, 2001; Marshall, 2007). Notable exceptions are cells in flies and mouse fibroblasts, which have been shown to divide without centrioles (Basto et al., 2006; Khodjakov et al., 2000). We frequently observed that the apical cytoplasm of Ecc cells, shortly after $\left[{ }^{3} \mathrm{H}\right]$ thymidine incorporation, contains many electron-dense particles that resembled basal body fragments, suggesting dynamic changes and possibly assembly and disassembly of these structures. It is possible that among these dense bodies some basic centriolar organization may be present and difficult to identify by serial reconstruction analysis. In one instance, 1 hour after thymidine injection we did observe a labeled cell with two structures, one adjacent to each of the two basal bodies, resembling emerging daughter centrioles (not shown). Centrioles in Ecc cells may be very short lived and we may have missed them in most cells. An alternative and intriguing possibility is that the two basal bodies, each associated to a cilium in Ecc cells, could act as centrioles during cell division without undergoing duplication. Consistently, some pairs of labeled Ecc cells observed at longer survivals after thymidine injection each had only one cilium. Moreover, we found several examples of Ecc cells with two nuclei in the walls of the central canal in adult mice. Binucleated neurons have been previously described in the adult brain (Alvarez-Dolado et al., 2003; Das, 1977; Magrassi et al., 2007), but to our knowledge this is the first description of binucleated cells in the ependymal layer. These cells could form through a cell fusion process, as described in the cerebellum for Purkinje neurons (Alvarez-Dolado et al., 2003). Alternatively, binucleated cells could be derived from dividing cells that failed to complete cytokinesis. Consistent with this possibility, we observed $\left[{ }^{3} \mathrm{H}\right]$ thymidine-labeled Ecc cells with four cilia 2.5 weeks after injection. Interestingly, a recent study by Anastas et al. in the developing cortex of mice deficient in Citron kinase, that have defective cytokinesis, results in the formation of neurons with multiple nuclei, centrioles and cilia (Anastas et al., 2011).

Central canal cells proliferated and remained in the central canal forming pairs. We did not find cells $\left(\left[{ }^{3} \mathrm{H}\right]\right.$ thymidine labeled or unlabeled) with the morphology of migrating cells, and the percentage of labeled central canal cells with respect to the total number of labeled cells in the spinal cord was similar after 1 hour or 2.5 weeks. The dorsoventral distribution of labeled cells was also maintained. Proliferation was not different along the cervical, thoracic 
and lumbar central canal, and did not vary with time. Therefore, it seems that basal Ecc proliferation does not substantially contribute to cells that migrate into the spinal cord parenchyma to differentiate into neurons and glial cells. This is consistent with a recent report using lineage tracing analysis of ependymal cells in the central canal of normal mice (Meletis et al., 2008). Instead the proliferation of Ecc cells was correlated with the dramatic postnatal growth of the spinal cord and corresponding lengthening of the central canal. We therefore conclude that Ecc cell proliferation may be part of the mechanism associated with the continual growth of the spinal cord after birth. However, we cannot exclude the possibility that some progeny from proliferating Ecc cells, especially during the period of rapid proliferation in juvenile mice, migrate away from the epithelium and contribute to cells in the spinal cord parenchyma.

It has been suggested that ependymomas, tumors with some ependymal characteristics, are derived from cells with radial glial properties (Poppleton and Gilbertson, 2007).

Ependymomas are found in periventricular regions, generally in the fourth ventricle, and are the most frequent spinal cord glioma, but are rare in the forebrain (Russell and Rubinstein, 1977). This could be related to the differential proliferative capacity of lateral ventricle vs. central canal ependymal cells. The present findings reveal a specialized type of ependymal cell in the central canal (Ecc) that continues to divide, albeit at slow rates, postnatally and could serve as the cell of origin for some ependymomas. It will be interesting to determine whether ependymomas share any of the characteristics we describe here for Ecc cells.

\section{The proliferative capacity of central canal astrocytes}

We found proliferating cells circumferentially around the central canal, but these cells were more common in the dorsal and ventral regions. Consistently, other studies have found increased incidence of Ki67+ cells dorsally, in a region of higher nestin expression (Hamilton et al., 2009). It has been suggested that these cells may correspond to neural stem cells. We found that nestin was expressed in GFAP+ astrocytes, but not in Ecc cells. Following a lesion or growth factor infusion, the expression of nestin is up-regulated (Martens et al., 2002; Mothe and Tator, 2005) and it is possible that, under these conditions, Ecc cells would start expressing this intermediate filament. One study (Sabourin et al., 2009) suggested that GFAP+ cells in the walls of the central canal can give rise to neurospheres in vitro, and could therefore correspond to in vivo stem cells. While we did observe a population of astrocytes contacting the central canal with a primary cilium, similar to the primary precursors in the lateral ventricle SVZ (Doetsch et al., 2002), we did not observe these cells proliferating under normal conditions. A robust proliferative response around the central canal has been shown after spinal cord lesioning (Beattie et al., 1997; Mothe and Tator, 2005; Namiki and Tator, 1999). It has been suggested, using lineage tracing experiments, that this response to injury is mediated by ependymal cells, which are activated and possibly give rise to parenchymal glial cells that migrate away from the epithelium (Meletis et al., 2008). Alternatively, central canal astrocytes may become activated in the setting of injury. We cannot rule out the possibility that central canal astrocytes are a quiescent progenitor cell population that divides infrequently and went undetected in the present study. We also cannot exclude the possibility that dividing Ecc cells under certain conditions could give rise to astrocytes.

\section{Central canal neurons}

CSF-contacting neurons have been described in spinal cord from cyclostomes to mammals (Vigh et al., 2004), but their function remains unclear. Immunocytochemical detection of different neurotransmitters, such as GABA or VIP (Barber et al., 1982; LaMotte, 1987), and the presence of synaptic vesicles (Vigh et al., 2004), suggest that they are functional neurons. They could act as receptors of CSF pressure, flow or composition. These neurons 
could also secrete factors into the CSF, or detect spinal cord movements through their contact with the Reissner fibre (Vigh et al., 2004). Recently, it has been shown that these cells have electrophysiological properties of immature neurons (Marichal et al., 2009), which is consistent with their expression of DCX, but not NeuN. Consistent with previous studies (Marichal et al., 2009; Sabourin et al., 2009), we did not find $\left[{ }^{3} \mathrm{H}\right]$ thymidine-labeled neurons in the adult central canal at 1 hour or 2.5 weeks after injection.

\section{Functional significance of Ecc cells}

The function of Ecc cells' specialized basal bodies and cilia is unknown. Interestingly, Ecc cells' cilia were frequently invaginated and closely associated to the Golgi apparatus. This Golgi association is rarely observed in cilia in E1 or E2 cells, but is common in progenitors with a primary cilium, including radial glia and adult SVZ astrocytes (Alvarez-Buylla et al., 1998; Gerdes et al., 2009; Sorokin, 1968). The primary cilium has recently been shown to have an important sensory function and to be essential for signal transduction of Shh and other extracellular signals (Goetz and Anderson, 2010; Han and Alvarez-Buylla, 2010; Wong and Reiter, 2008). This raises the intriguing possibility that Ecc cilia, with their specialized basal body, may function as sensory organelles sampling molecular signals within the cerebrospinal fluid, in addition to the mechanical role of propelling the fluid. Further work to identify molecular components of the basal body that may distinguish different types of ependymal cells is likely to provide clues about the diversification of ependymal cell types and a better understanding of their respective developmental origin and function.

Most Ecc cells were found in contact with an extensive network of basal lamina, resembling that observed in the SVZ (Mercier et al., 2002). Extracellular matrix components have been suggested to play important roles in the regulation of progenitor cells within adult germinal niches (Kerever et al., 2007; Mercier et al., 2002; Shen et al., 2008). Direct contact with blood vessels, which is essential both in the adult and embryonic brain (Alvarez-Buylla and Lim, 2004), may also be related to the function of Ecc cells.

\section{Tanycytes vs. Ecc cells}

Classically, the term tanycyte has been used to describe a cell in contact with the ventricular system that has a long radial process with extension to the pial surface or to blood vessels (Bruni, 1998; Horstmann, 1954; Rafols and Goshgarian, 1985). In the adult mammalian brain, tanycytes are generally thought to be restricted to certain regions, like the third ventricle (Bruni, 1998). However, both in the lateral ventricles and in the spinal cord neuroepithelium, the definition of tanycyte is still controversial. In the central canal, cells located at the dorsal and ventral regions and retaining contact with the pial surface were frequently described as tanycytes, in contrast to ependymal cells (Seitz et al., 1981). However, more recent studies do not agree on the canal cell types. While some authors still identify tanycytes (Mothe and Tator, 2005) or tanycyte-like cells (Hamilton et al., 2009) as those predominantly located in the dorsal or ventral regions in the central canal, others define tanycytes as radial cells also present in the lateral walls, coexisting with cuboidal and radial ependymal cells (Meletis et al., 2008). Frequently, tanycytes are not mentioned in descriptions of the central canal (Bjugn et al., 1988). Our data show that the central canal is mostly composed of Ecc cells with radial processes, both in the poles and the lateral walls of the canal, possibly corresponding to the frequently described tanycyte-like cells.

In conclusion, we describe the characteristics of Ecc cells, the most abundant cells in the central canal. We show that they differ significantly from classical multiciliated ependymal cells. Ecc cells possess large, electron-dense basal bodies that nucleate one or two long motile cilia, and express vimentin, CD24, FoxJ1, Sox2 and CD133, but not nestin or GFAP. 
These cells can divide, but do not appear to generate, under normal conditions, parenchymal progeny. Instead, their proliferation was closely correlated with the growth and elongation of the spinal cord. This work reveals the diversity of ependymal cell types and their respective functions as both motors driving CSF flow and receptors sensing its composition.

\title{
Supplementary Material
}

Refer to Web version on PubMed Central for supplementary material.

\section{Acknowledgments}

\begin{abstract}
We would like to acknowledge the excellent technical assistance of Patricia García Tarraga, Arantxa Cebrián Silla and Erika Via, Ulises Gómez Pinedo, and Eva Escorihuela for her technical support at the CIPF Confocal Microscopy Service. Scanning Electron Microscopy was carried out at the Electron Microscopy Service of the University of Valencia.

The work was supported by grants from the Spanish Ministry of Science and Innovation (SAF-2008-01274 to J.M.G.V. and AP-2004-2261 to C.A.C.); Instituto de Salud Carlos III, Red de Terapia Celular (RD06/0010/0022); NIH (HD32116, NS28478), John G. Bowes Research Fund and the Sandler Foundation (to A.A.B). A.A.B is the Heather and Melanie Muss Endowed Chair of Neurological Surgery at UCSF.
\end{abstract}

\section{Bibliography}

Alfaro-Cervello, C.; Soriano-Navarro, M.; Gomez-Pinedo, U.; García-Verdugo, J. Correlation of light and electron microscopy for immunogold staining. GFP immunogold, tool in biological research. In: Mendez-Vilas, A.; Diaz, J., editors. Microscopy: Science, Technology. Applications and Education: Formatex Microscopy Book Series; 2010.

Alvarez-Buylla A, Garcia-Verdugo JM, Mateo AS, Merchant-Larios H. Primary neural precursors and intermitotic nuclear migration in the ventricular zone of adult canaries. J Neurosci. 1998; 18(3): 1020-1037. [PubMed: 9437023]

Alvarez-Buylla A, Lim DA. For the long run: maintaining germinal niches in the adult brain. Neuron. 2004; 41(5):683-686. [PubMed: 15003168]

Alvarez-Dolado M, Pardal R, Garcia-Verdugo JM, Fike JR, Lee HO, Pfeffer K, Lois C, Morrison SJ, Alvarez-Buylla A. Fusion of bone-marrow-derived cells with Purkinje neurons, cardiomyocytes and hepatocytes. Nature. 2003; 425(6961):968-973. [PubMed: 14555960]

Anastas SB, Mueller D, Semple-Rowland SL, Breunig JJ, Sarkisian MR. Failed cytokinesis of neural progenitors in citron kinase-deficient rats leads to multiciliated neurons. Cereb Cortex. 2011; 21(2): 338-344. [PubMed: 20525772]

Barber RP, Vaughn JE, Roberts E. The cytoarchitecture of GABAergic neurons in rat spinal cord. Brain research. 1982; 238(2):305-328. [PubMed: 7046873]

Basto R, Lau J, Vinogradova T, Gardiol A, Woods CG, Khodjakov A, Raff JW. Flies without centrioles. Cell. 2006; 125(7):1375-1386. [PubMed: 16814722]

Beattie MS, Bresnahan JC, Komon J, Tovar CA, Van Meter M, Anderson DK, Faden AI, Hsu CY, Noble LJ, Salzman S, Young W. Endogenous repair after spinal cord contusion injuries in the rat. Experimental neurology. 1997; 148(2):453-463. [PubMed: 9417825]

Bjugn R, Haugland HK, Flood PR. Ultrastructure of the mouse spinal cord ependyma. Journal of anatomy. 1988; 160:117-125. [PubMed: 3253250]

Bradbury MW, Lathem W. A flow of cerebrospinal fluid along the central canal of the spinal cord of the rabbit and communications between this canal and the sacral subarachnoid space. J Physiol. 1965; 181(4):785-800. [PubMed: 5881254]

Brandt MD, Jessberger S, Steiner B, Kronenberg G, Reuter K, Bick-Sander A, von der Behrens W, Kempermann G. Transient calretinin expression defines early postmitotic step of neuronal differentiation in adult hippocampal neurogenesis of mice. Mol Cell Neurosci. 2003; 24(3):603613. [PubMed: 14664811] 
Brown JP, Couillard-Despres S, Cooper-Kuhn CM, Winkler J, Aigner L, Kuhn HG. Transient expression of doublecortin during adult neurogenesis. The Journal of comparative neurology. 2003; 467(1):1-10. [PubMed: 14574675]

Bruni JE. Ependymal development, proliferation, and functions: a review. Microscopy research and technique. 1998; 41(1):2-13. [PubMed: 9550133]

Capela A, Temple S. LeX/ssea-1 is expressed by adult mouse CNS stem cells, identifying them as nonependymal. Neuron. 2002; 35(5):865-875. [PubMed: 12372282]

Chiasson BJ, Tropepe V, Morshead CM, van der Kooy D. Adult mammalian forebrain ependymal and subependymal cells demonstrate proliferative potential, but only subependymal cells have neural stem cell characteristics. J Neurosci. 1999; 19(11):4462-4471. [PubMed: 10341247]

Crespo C, Gracia-Llanes FJ, Blasco-Ibanez JM, Gutierrez-Mecinas M, Marques-Mari AI, MartinezGuijarro FJ. Nitric oxide synthase containing periglomerular cells are GABAergic in the rat olfactory bulb. Neuroscience letters. 2003; 349(3):151-154. [PubMed: 12951191]

Das GD. Binucleated neurons in the central nervous system of the laboratory animals. Experientia. 1977; 33(9):1179-1180. [PubMed: 891866]

Debus E, Weber K, Osborn M. Monoclonal antibodies specific for glial fibrillary acidic (GFA) protein and for each of the neurofilament triplet polypeptides. Differentiation. 1983; 25(2):193-203. [PubMed: 6198232]

Dirksen ER. Centriole morphogenesis in developing ciliated epithelium of the mouse oviduct. The Journal of cell biology. 1971; 51(1):286-302. [PubMed: 5111878]

Doetsch F, Caille I, Lim DA, Garcia-Verdugo JM, Alvarez-Buylla A. Subventricular zone astrocytes are neural stem cells in the adult mammalian brain. Cell. 1999; 97(6):703-716. [PubMed: 10380923]

Doetsch F, Garcia-Verdugo JM, Alvarez-Buylla A. Cellular composition and three-dimensional organization of the subventricular germinal zone in the adult mammalian brain. J Neurosci. 1997; 17(13):5046-5061. [PubMed: 9185542]

Doetsch F, Petreanu L, Caille I, Garcia-Verdugo JM, Alvarez-Buylla A. EGF converts transitamplifying neurogenic precursors in the adult brain into multipotent stem cells. Neuron. 2002; 36(6):1021-1034. [PubMed: 12495619]

Dromard C, Guillon H, Rigau V, Ripoll C, Sabourin JC, Perrin FE, Scamps F, Bozza S, Sabatier P, Lonjon N, Duffau H, Vachiery-Lahaye F, Prieto M, Tran Van Ba C, Deleyrolle L, Boularan A, Langley K, Gaviria M, Privat A, Hugnot JP, Bauchet L. Adult human spinal cord harbors neural precursor cells that generate neurons and glial cells in vitro. Journal of neuroscience research. 2008; 86(9):1916-1926. [PubMed: 18335522]

Gerdes JM, Davis EE, Katsanis N. The vertebrate primary cilium in development, homeostasis, and disease. Cell. 2009; 137(1):32-45. [PubMed: 19345185]

Goetz SC, Anderson KV. The primary cilium: a signalling centre during vertebrate development. Nat Rev Genet. 2010; 11(5):331-344. [PubMed: 20395968]

Gonzalez-Perez O, Romero-Rodriguez R, Soriano-Navarro M, Garcia-Verdugo JM, Alvarez-Buylla A. Epidermal growth factor induces the progeny of subventricular zone type B cells to migrate and differentiate into oligodendrocytes. Stem cells (Dayton, Ohio). 2009; 27(8):2032-2043.

Gritti A, Parati EA, Cova L, Frolichsthal P, Galli R, Wanke E, Faravelli L, Morassutti DJ, Roisen F, Nickel DD, Vescovi AL. Multipotential stem cells from the adult mouse brain proliferate and selfrenew in response to basic fibroblast growth factor. J Neurosci. 1996; 16(3):1091-1100. [PubMed: 8558238]

Hamilton LK, Truong MK, Bednarczyk MR, Aumont A, Fernandes KJ. Cellular organization of the central canal ependymal zone, a niche of latent neural stem cells in the adult mammalian spinal cord. Neuroscience. 2009

Han YG, Alvarez-Buylla A. Role of primary cilia in brain development and cancer. Current opinion in neurobiology. 2010; 20(1):58-67. [PubMed: 20080044]

Hinchcliffe EH, Miller FJ, Cham M, Khodjakov A, Sluder G. Requirement of a centrosomal activity for cell cycle progression through G1 into S phase. Science (New York, NY. 2001; 291(5508): $1547-1550$. 
Hockfield S, McKay RD. Identification of major cell classes in the developing mammalian nervous system. J Neurosci. 1985; 5(12):3310-3328. [PubMed: 4078630]

Horner PJ, Power AE, Kempermann G, Kuhn HG, Palmer TD, Winkler J, Thal LJ, Gage FH. Proliferation and differentiation of progenitor cells throughout the intact adult rat spinal cord. $\mathrm{J}$ Neurosci. 2000; 20(6):2218-2228. [PubMed: 10704497]

Horstmann E. Die Faserglia des Selachiergehirns Z Zellforsch. 1954; 39:588. 617.

Huang T, You Y, Spoor MS, Richer EJ, Kudva VV, Paige RC, Seiler MP, Liebler JM, Zabner J, Plopper CG, Brody SL. Foxj1 is required for apical localization of ezrin in airway epithelial cells. Journal of cell science. 2003; 116(Pt 24):4935-4945. [PubMed: 14625387]

Jacquet BV, Salinas-Mondragon R, Liang H, Therit B, Buie JD, Dykstra M, Campbell K, Ostrowski LE, Brody SL, Ghashghaei HT. FoxJ1-dependent gene expression is required for differentiation of radial glia into ependymal cells and a subset of astrocytes in the postnatal brain. Development. 2009; 136(23):4021-4031. [PubMed: 19906869]

Kee N, Sivalingam S, Boonstra R, Wojtowicz JM. The utility of Ki-67 and BrdU as proliferative markers of adult neurogenesis. Journal of neuroscience methods. 2002; 115(1):97-105. [PubMed: 11897369]

Kerever A, Schnack J, Vellinga D, Ichikawa N, Moon C, Arikawa-Hirasawa E, Efird JT, Mercier F. Novel extracellular matrix structures in the neural stem cell niche capture the neurogenic factor fibroblast growth factor 2 from the extracellular milieu. Stem cells (Dayton, Ohio). 2007; 25(9): 2146-2157.

Khodjakov A, Cole RW, Oakley BR, Rieder CL. Centrosome-independent mitotic spindle formation in vertebrates. Curr Biol. 2000; 10(2):59-67. [PubMed: 10662665]

Khodjakov A, Rieder CL. Centrosomes enhance the fidelity of cytokinesis in vertebrates and are required for cell cycle progression. The Journal of cell biology. 2001; 153(1):237-242. [PubMed: 11285289]

Kojima A, Tator CH. Epidermal growth factor and fibroblast growth factor 2 cause proliferation of ependymal precursor cells in the adult rat spinal cord in vivo. J Neuropathol Exp Neurol. 2000; 59(8):687-697. [PubMed: 10952059]

Komatsu M, Fujita H. Electron-microscopic studies on the development and aging of the oviduct epithelium of mice. Anat Embryol (Berl). 1978; 152(3):243-259. [PubMed: 655432]

Komitova M, Eriksson PS. Sox-2 is expressed by neural progenitors and astroglia in the adult rat brain. Neuroscience letters. 2004; 369(1):24-27. [PubMed: 15380301]

Kramer-Zucker AG, Olale F, Haycraft CJ, Yoder BK, Schier AF, Drummond IA. Cilia-driven fluid flow in the zebrafish pronephros, brain and Kupffer's vesicle is required for normal organogenesis. Development. 2005; 132(8):1907-1921. [PubMed: 15790966]

LaMotte CC. Vasoactive intestinal polypeptide cerebrospinal fluid-contacting neurons of the monkey and cat spinal central canal. The Journal of comparative neurology. 1987; 258(4):527-541. [PubMed: 2438312]

Laywell ED, Rakic P, Kukekov VG, Holland EC, Steindler DA. Identification of a multipotent astrocytic stem cell in the immature and adult mouse brain. Proceedings of the National Academy of Sciences of the United States of America. 2000; 97(25):13883-13888. [PubMed: 11095732]

Lendahl U, Zimmerman LB, McKay RD. CNS stem cells express a new class of intermediate filament protein. Cell. 1990; 60(4):585-595. [PubMed: 1689217]

Lois C, Alvarez-Buylla A. Proliferating subventricular zone cells in the adult mammalian forebrain can differentiate into neurons and glia. Proceedings of the National Academy of Sciences of the United States of America. 1993; 90(5):2074-2077. [PubMed: 8446631]

Luo J, Shook BA, Daniels SB, Conover JC. Subventricular zone-mediated ependyma repair in the adult mammalian brain. J Neurosci. 2008; 28(14):3804-3813. [PubMed: 18385338]

Magrassi L, Grimaldi P, Ibatici A, Corselli M, Ciardelli L, Castello S, Podesta M, Frassoni F, Rossi F. Induction and survival of binucleated Purkinje neurons by selective damage and aging. J Neurosci. 2007; 27(37):9885-9892. [PubMed: 17855603]

Marichal N, Garcia G, Radmilovich M, Trujillo-Cenoz O, Russo RE. Enigmatic central canal contacting cells: immature neurons in "standby mode"? J Neurosci. 2009; 29(32):10010-10024. [PubMed: 19675235] 
Marshall WF. What is the function of centrioles? J Cell Biochem. 2007; 100(4):916-922. [PubMed: 17115414]

Martens DJ, Seaberg RM, van der Kooy D. In vivo infusions of exogenous growth factors into the fourth ventricle of the adult mouse brain increase the proliferation of neural progenitors around the fourth ventricle and the central canal of the spinal cord. The European journal of neuroscience. 2002; 16(6):1045-1057. [PubMed: 12383233]

Meletis K, Barnabe-Heider F, Carlen M, Evergren E, Tomilin N, Shupliakov O, Frisen J. Spinal cord injury reveals multilineage differentiation of ependymal cells. PLoS biology. 2008; 6(7):e182. [PubMed: 18651793]

Menn B, Garcia-Verdugo JM, Yaschine C, Gonzalez-Perez O, Rowitch D, Alvarez-Buylla A. Origin of oligodendrocytes in the subventricular zone of the adult brain. J Neurosci. 2006; 26(30):79077918. [PubMed: 16870736]

Mercier F, Kitasako JT, Hatton GI. Anatomy of the brain neurogenic zones revisited: fractones and the fibroblast/macrophage network. The Journal of comparative neurology. 2002; 451(2):170-188. [PubMed: 12209835]

Mirzadeh Z, Han YG, Soriano-Navarro M, Garcia-Verdugo JM, Alvarez-Buylla A. Cilia organize ependymal planar polarity. J Neurosci. 2010; 30(7):2600-2610. [PubMed: 20164345]

Mirzadeh Z, Merkle FT, Soriano-Navarro M, Garcia-Verdugo JM, Alvarez-Buylla A. Neural stem cells confer unique pinwheel architecture to the ventricular surface in neurogenic regions of the adult brain. Cell stem cell. 2008; 3(3):265-278. [PubMed: 18786414]

Mothe AJ, Tator $\mathrm{CH}$. Proliferation, migration, and differentiation of endogenous ependymal region stem/progenitor cells following minimal spinal cord injury in the adult rat. Neuroscience. 2005; 131(1):177-187. [PubMed: 15680701]

Nakayama Y, Kohno K. Number and polarity of the ependymal cilia in the central canal of some vertebrates. J Neurocytol. 1974; 3(4):449-458. [PubMed: 4436691]

Namiki J, Tator $\mathrm{CH}$. Cell proliferation and nestin expression in the ependyma of the adult rat spinal cord after injury. J Neuropathol Exp Neurol. 1999; 58(5):489-498. [PubMed: 10331437]

Nonaka S, Tanaka Y, Okada Y, Takeda S, Harada A, Kanai Y, Kido M, Hirokawa N. Randomization of left-right asymmetry due to loss of nodal cilia generating leftward flow of extraembryonic fluid in mice lacking KIF3B motor protein. Cell. 1998; 95(6):829-837. [PubMed: 9865700]

Oakley BR. Gamma-tubulin: the microtubule organizer? Trends in cell biology. 1992; 2(1):1-5. [PubMed: 14731630]

Otani EM, Newkirk C, McDowell EM. Development of hamster tracheal epithelium: IV. Cell proliferation and cytodifferentiation in the neonate. The Anatomical record. 1986; 214(2):183192. [PubMed: 3954074]

Peters, E.; Palay, SL.; Webster, HdF. The fine structure of the nervous system: neurons and their supporting cells. New York: Oxford UP; 1991.

Poppleton H, Gilbertson RJ. Stem cells of ependymoma. Br J Cancer. 2007; 96(1):6-10. [PubMed: 17179988]

Rafols JA, Goshgarian HG. Spinal tanycytes in the adult rat: a correlative Golgi gold-toning study. The Anatomical record. 1985; 211(1):75-86. [PubMed: 3985381]

Rawlins EL, Ostrowski LE, Randell SH, Hogan BL. Lung development and repair: contribution of the ciliated lineage. Proceedings of the National Academy of Sciences of the United States of America. 2007; 104(2):410-417. [PubMed: 17194755]

Russell, D.; Rubinstein, L. Pathology of Tumours of the Nervous System. London: Edward Arnold; 1977.

Sabourin JC, Ackema KB, Ohayon D, Guichet PO, Perrin FE, Garces A, Ripoll C, Charite J, Simonneau L, Kettenmann H, Zine A, Privat A, Valmier J, Pattyn A, Hugnot JP. A mesenchymallike ZEB1(+) niche harbors dorsal radial glial fibrillary acidic protein-positive stem cells in the spinal cord. Stem cells (Dayton, Ohio). 2009; 27(11):2722-2733.

Sanai N, Tramontin AD, Quinones-Hinojosa A, Barbaro NM, Gupta N, Kunwar S, Lawton MT, McDermott MW, Parsa AT, Manuel-Garcia Verdugo J, Berger MS, Alvarez-Buylla A. Unique astrocyte ribbon in adult human brain contains neural stem cells but lacks chain migration. Nature. 2004; 427(6976):740-744. [PubMed: 14973487] 
Satir P, Christensen ST. Overview of structure and function of mammalian cilia. Annu Rev Physiol. 2007; 69:377-400. [PubMed: 17009929]

Seitz R, Lohler J, Schwendemann G. Ependyma and meninges of the spinal cord of the mouse. A light-and electron-microscopic study. Cell and tissue research. 1981; 220(1):61-72. [PubMed: 7273132]

Shen Q, Wang Y, Kokovay E, Lin G, Chuang SM, Goderie SK, Roysam B, Temple S. Adult SVZ stem cells lie in a vascular niche: a quantitative analysis of niche cell-cell interactions. Cell stem cell. 2008; 3(3):289-300. [PubMed: 18786416]

Shibuya S, Miyamoto O, Auer RN, Itano T, Mori S, Norimatsu H. Embryonic intermediate filament, nestin, expression following traumatic spinal cord injury in adult rats. Neuroscience. 2002; 114(4): 905-916. [PubMed: 12379246]

Sorokin SP. Reconstructions of centriole formation and ciliogenesis in mammalian lungs. Journal of cell science. 1968; 3(2):207-230. [PubMed: 5661997]

Spassky N, Merkle FT, Flames N, Tramontin AD, Garcia-Verdugo JM, Alvarez-Buylla A. Adult ependymal cells are postmitotic and are derived from radial glial cells during embryogenesis. $\mathrm{J}$ Neurosci. 2005; 25(1):10-18. [PubMed: 15634762]

Vigh B, Manzano e Silva Mj, Frank CL, Vincze C, Czirok SJ, Szabo A, Lukats A, Szel A. The system of cerebrospinal fluid-contacting neurons. Its supposed role in the nonsynaptic signal transmission of the brain. Histology and histopathology. 2004; 19(2):607-628. [PubMed: 15024719]

Weigmann A, Corbeil D, Hellwig A, Huttner WB. Prominin, a novel microvilli-specific polytopic membrane protein of the apical surface of epithelial cells, is targeted to plasmalemmal protrusions of non-epithelial cells. Proceedings of the National Academy of Sciences of the United States of America. 1997; 94(23):12425-12430. [PubMed: 9356465]

Weiss S, Dunne C, Hewson J, Wohl C, Wheatley M, Peterson AC, Reynolds BA. Multipotent CNS stem cells are present in the adult mammalian spinal cord and ventricular neuroaxis. J Neurosci. 1996; 16(23):7599-7609. [PubMed: 8922416]

Wong SY, Reiter JF. The primary cilium at the crossroads of mammalian hedgehog signaling. Curr Top Dev Biol. 2008; 85:225-260. [PubMed: 19147008]

Zhang Y, Huang G, Shornick LP, Roswit WT, Shipley JM, Brody SL, Holtzman MJ. A transgenic FOXJ1-Cre system for gene inactivation in ciliated epithelial cells. Am J Respir Cell Mol Biol. 2007; 36(5):515-519. [PubMed: 17255554] 

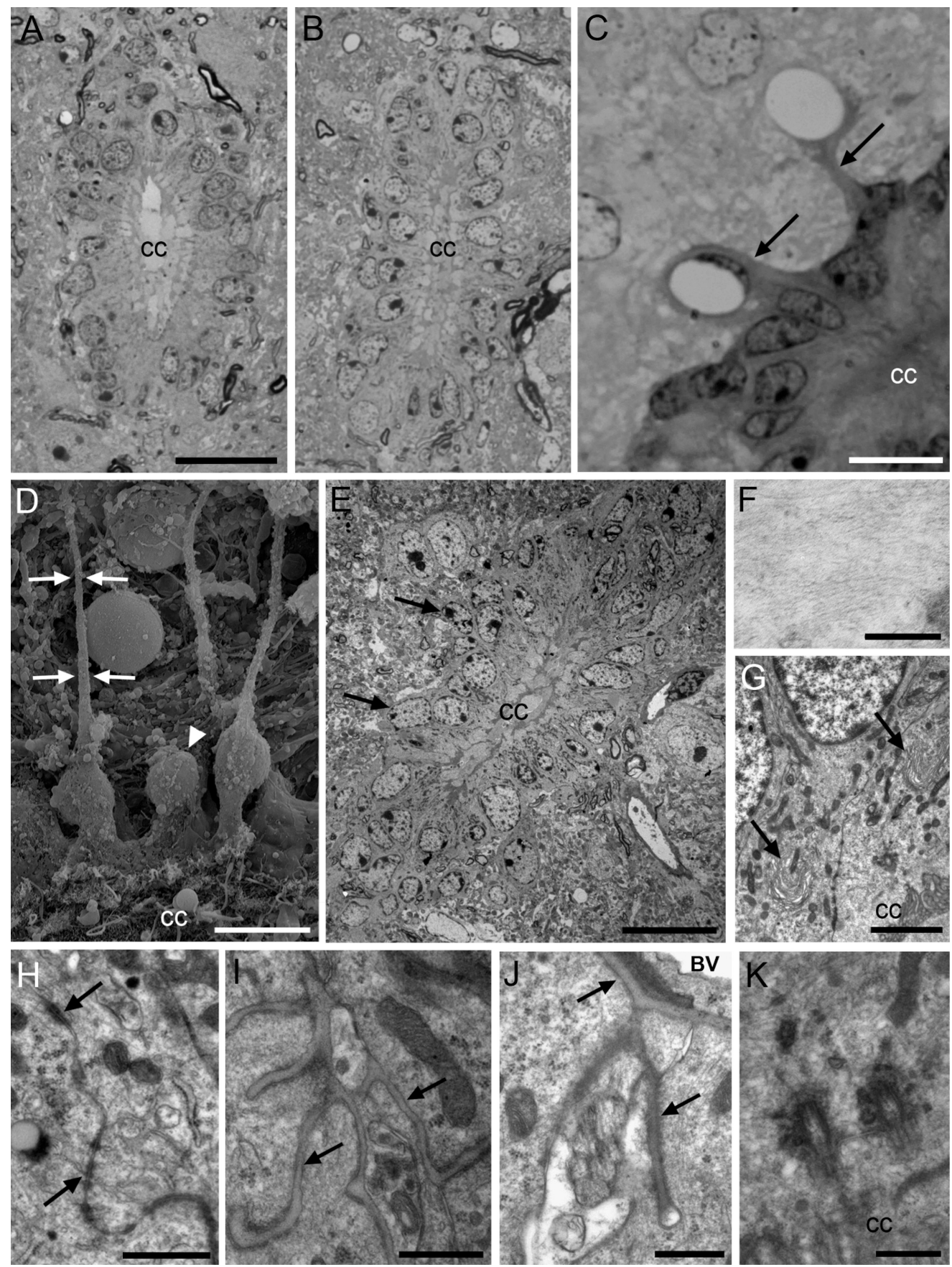

\section{Figure 1. Central canal ependymal (Ecc) cells}

A) Toluidine blue-stained semithin section of the cervical spinal cord, where the central canal shows an oval shape. B) The lumbar central canal is dorsoventrally elongated. C) Central canal cells in the lateral wall, with radial expansions (arrows) in contact with blood vessels. D) Scanning electron microscopy (SEM) image of the canal surface (below). Some cells show long and thin basal processes (arrows), and other cells show rounder cell bodies, without radial process (arrowhead). E) Cells in the central canal are organized as a pseudostratified epithelium, with most nuclei located in the apical row, and some of them in basal position (arrows). The dorsal and ventral regions of the canal (up and below respectively) contain elongated Ecc cells with long radial processes. Blood vessels in close 
association to the canal can be observed. F) Detail of intermediate filaments of an Ecc cell. G) Horse-shoe shaped Golgi apparatuses polarized with the cis-side pointing at the apical surface (arrows). H) Large junction complexes are found apically between adjacent cells (arrows). I) Basal lamina network flowing through Ecc cells (arrows). J) Radial process of a central canal ependymal cell in contact with the basal lamina (arrows) of a blood vessel. K) Two large and electron-dense basal bodies of a biciliated Ecc cell. A-C are toluidine bluestained semithin sections, and E-K are transmission electron microscopy (TEM) images. CC, central canal; BV, blood vessel. Scale bar in A (A-B) and E, $20 \mu \mathrm{m}$; C and D, $10 \mu \mathrm{m}$; F, 200nm; G, $2 \mu \mathrm{m}$; H, $1 \mu \mathrm{m}$; I, J and K, $500 \mathrm{~nm}$. 

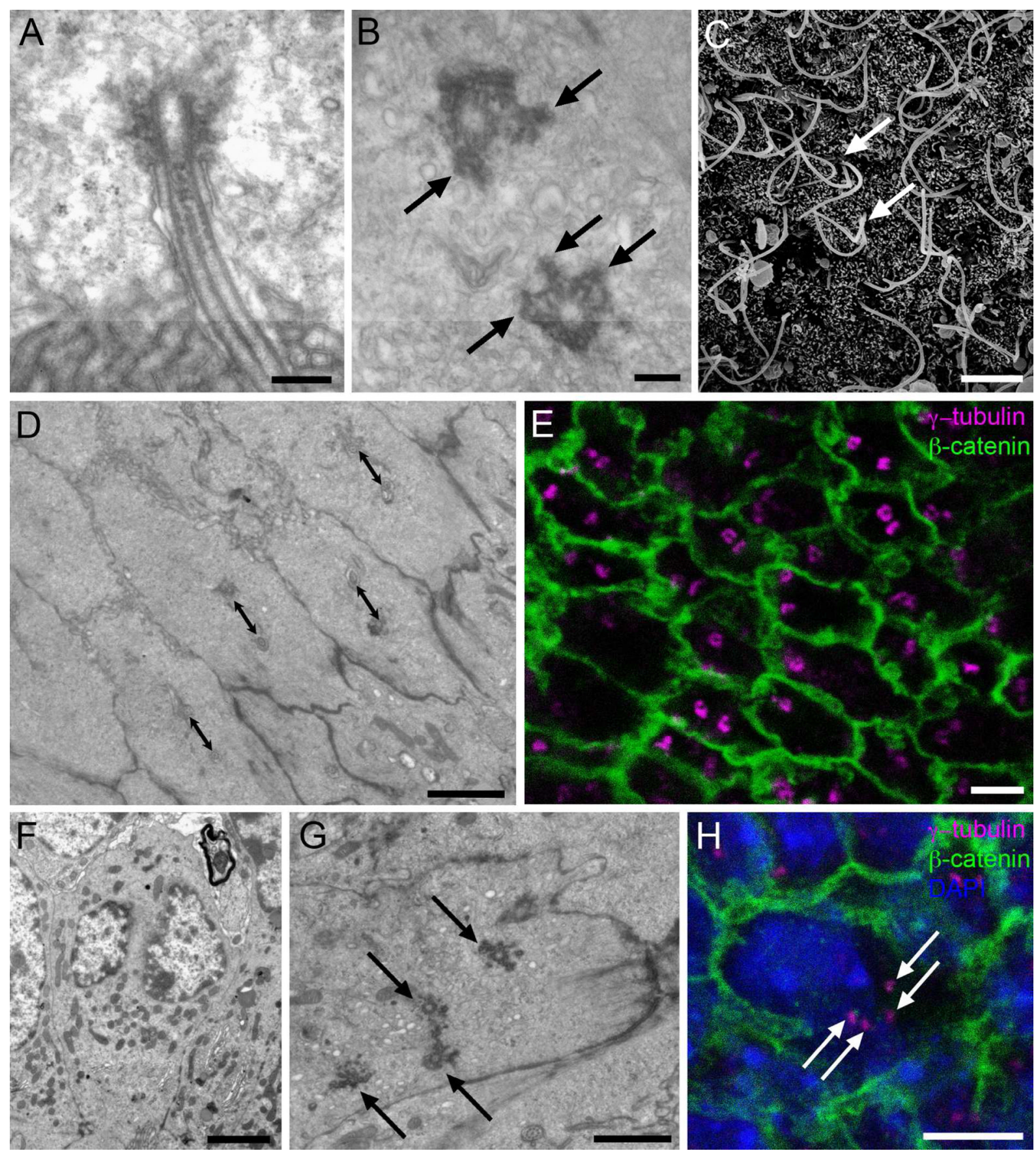

Figure 2. Cilia and basal bodies of Ecc cells

A) Longitudinal TEM section of a cilium, showing the axoneme with a central pair of microtubules and a large electron-dense basal body. B) Tangential TEM section of the canal surface, showing basal bodies with multiple electron-dense appendages organized as radial spikes (arrows). C) SEM image of the canal surface, were long cilia can be observed as they emerge in parallel (arrows). No multiciliated cells were observed. D) Tangential TEM section of the canal surface, showing that biciliated Ecc cells' basal bodies are oriented in the same direction and at a similar distance (double sided arrows: $1 \mu \mathrm{m}$ ). E)

Immunofluorescence on central canal whole mount preparation. Donut-shaped basal bodies can be observed, stained with $\gamma$-tubulin (magenta), and limits between adjacent cells can be 
followed with $\beta$-catenin expression (green). F) TEM image showing an Ecc cell with two distinct nuclei, confirmed by serial ultrathin sectioning. G) En-face TEM section of the central canal surface showing one cell with four basal bodies (arrows). H) Confocal immunostaining on central canal whole mounts confirmed the presence of cells with two nuclei (DAPI, blue), and four basal bodies ( $\mathrm{Y}$-tubulin, magenta). Cell contours are labeled in green ( $\beta$-catenin). Scale bar in A and B, $200 \mathrm{~nm} ; \mathrm{C}, 5 \mu \mathrm{m} ; \mathrm{D}, \mathrm{E}, \mathrm{F}$ and H, $2 \mu \mathrm{m} ; \mathrm{G}, 1 \mu \mathrm{m}$. 

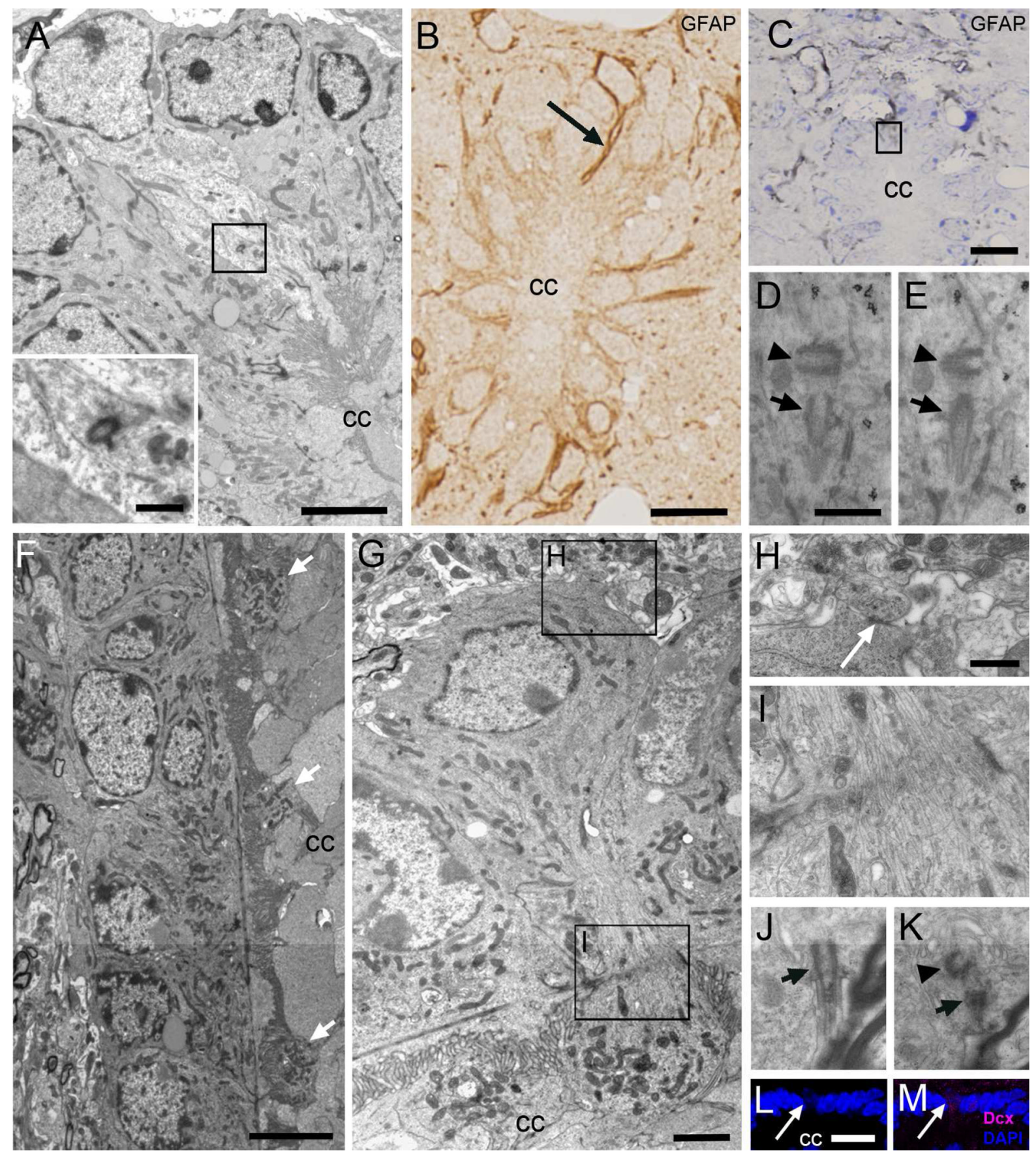

Figure 3. Astrocytes and neurons in contact with the central canal (Acc and Ncc cells)

A) Ultrastructure of an Acc cell with light cytoplasm in contact with the canal in the dorsal region in a transverse TEM section, showing an orthogonally oriented centriole (inset). B) Post-embedding immunocytochemistry on semithin sections, showing a thin GFAP+ expansion in contact with the canal lumen (arrow). C-E) Pre-embedding immunogold (detection of GFAP. C) Toluidine blue-stained semithin section showing grey immunogoldsilver labeling for GFAP around the central canal and in thin expansions in contact with its lumen (boxed area). D-E) TEM serial sectioning of the box in C. One of the labeled cells displays a typical single cilium basal body (arrow) with an orthogonally oriented centriole (arrowhead). F) Longitudinal TEM section of the canal where globular expansions of several 
Ncc cells can be detected (arrows). G) These neurons show a round soma, and their cytoplasm contains abundant mitochondria and RER. H) Ncc cells establish axo-somatic synaptic contacts (arrow) in the surrounding neuropil. I) The apical narrowing contains abundant microtubules. J-K) Single cilium (arrow) with centriole (arrowhead) in a different Ncc cell that was serially reconstructed. L-M) Confocal immunofluorescence shows that Ncc cells express DCX (magenta) and their nuclei are weakly stained with DAPI (blue). CC, central canal. Scale bar in A and G, $2 \mu \mathrm{m}$, inbox, $500 \mathrm{~nm}$; B, C and L, $10 \mu \mathrm{m}$; D (D-E) and $\mathrm{H}(\mathrm{H}-\mathrm{K}), 500 \mathrm{~nm}$ and; F, $5 \mu \mathrm{m}$. 

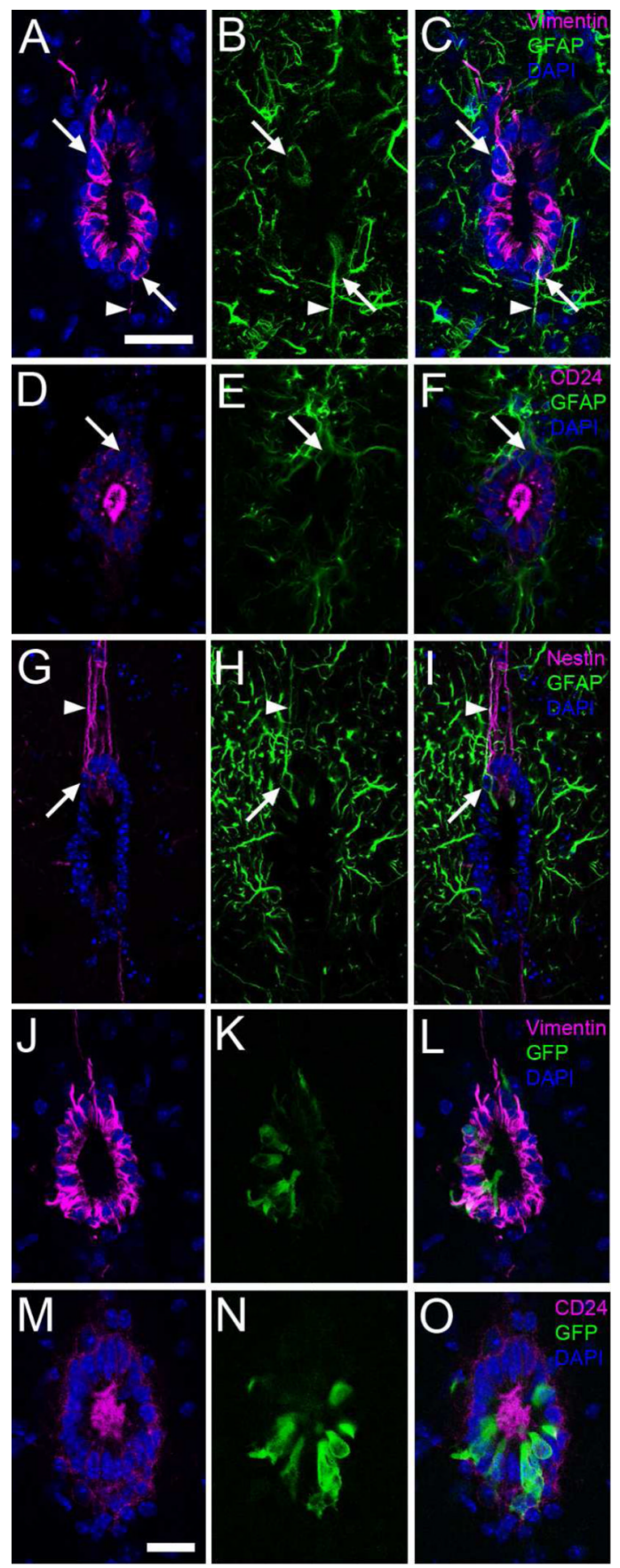

Figure 4. Molecular markers in the central canal

A-C) Most central canal cells express vimentin intermediate filaments (magenta). Some cells also contain GFAP (green, arrows). GFAP is also frequent outside the canal. Some cells also express GFAP and vimentin in long processes (arrowheads). D-F) Nearly all canal cells express CD24 (magenta). Arrows point to a CD24- cell expressing GFAP (green). G-I) Nestin (magenta) was expressed predominantly in the dorsal and ventral regions of the central canal, especially in very long dorsal radial processes, which were frequently also positive for GFAP (green, arrowheads). The arrows point to a nestin+ cell also labeled with GFAP. J-O) Expression of FoxJ1 in the FoxJ1 ::Cre;Z/EG mice. J-L) FoxJ1 (green) is also expressed by vimentin+ cells (magenta). M-O) Immunofluorescence for GFP (green) and 
CD24 (magenta). Nuclei are stained with DAPI (blue). Scale bar in A (A-L), $20 \mu \mathrm{m}$; M (MO), $10 \mu \mathrm{m}$. 

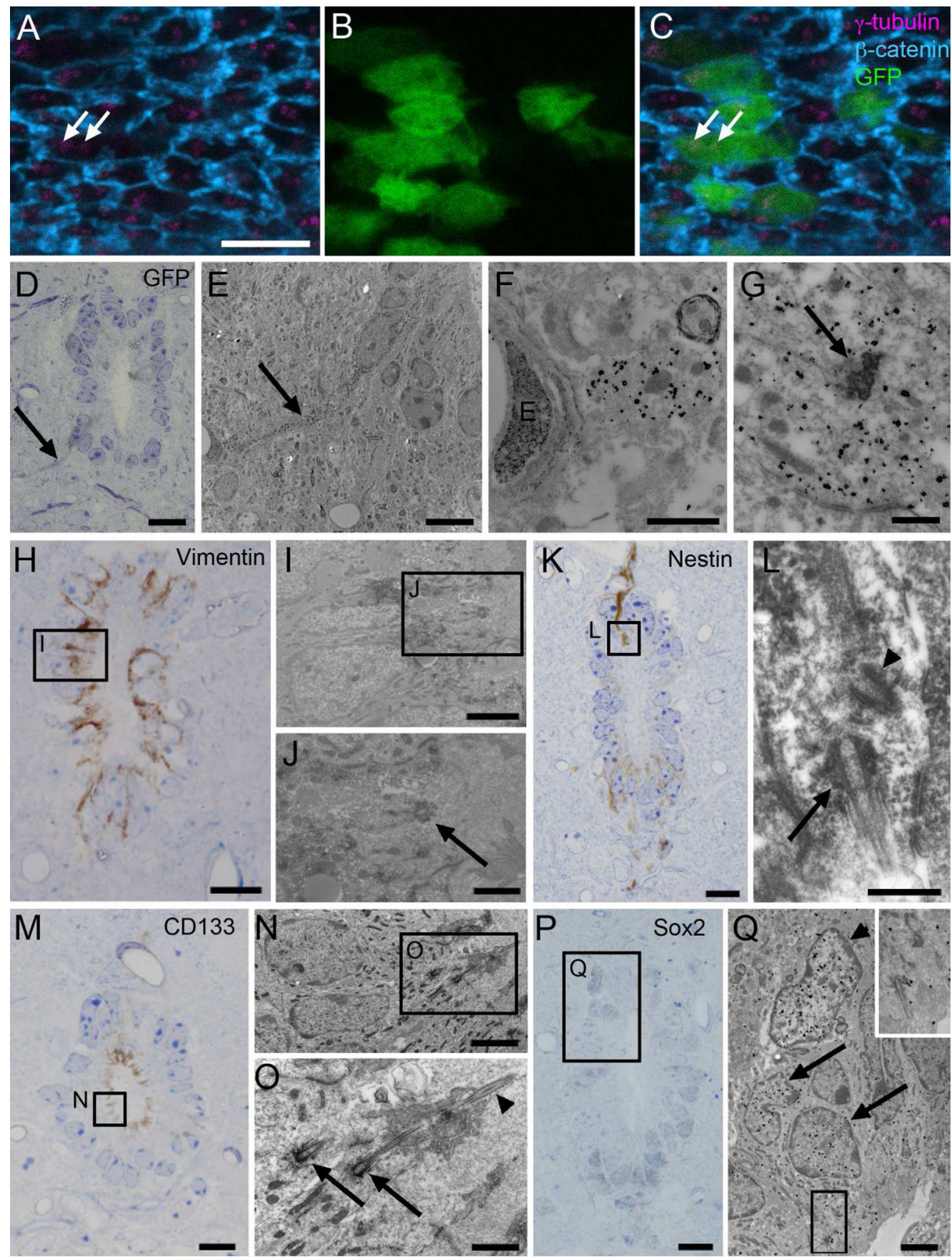

Figure 5. Characterization of central canal cells

A-C) Confocal immunofluorescence on central canal whole mounts of the FoxJ1 ::Cre;Z/ EG mice shows that GFP+ cells (green) display two basal bodies ( $\gamma$-tubulin, magenta, arrows). $\beta$-catenin is shown in blue. D-G) Pre-embedding immunogold for GFP, showing several FoxJ1+ cells, one of them with a long radial process (arrows in D and E) in contact with a blood vessel. E) TEM of the same radial cell (arrow) labeled with silver-gold particles. F) Detail of the contact with the blood vessel's basal lamina. G) Characteristic Ecc basal body (arrow) in a labeled cell. H-J) Pre-embedding staining for vimentin showed that labeled cells corresponded to Ecc cells with large electron-dense basal bodies (arrow). K-L) Nestin pre-embedding staining labeled cells with a single cilium (arrow) and centriole 
(arrowhead) in the dorsal and ventral regions of the canal. M-O) Pre-embedding staining for CD133 was detected along the apical surface of Ecc cells with large electron-dense basal bodies (arrows) and 9+2 axoneme (arrowhead). P-Q) Sox 2 pre-embedding immunogold staining labeled both Acc cells (arrowhead) and Ecc cells (arrows) in the central canal. Inset shows characteristic basal bodies and cilia of Ecc cells. D, H, K, M and P are toluidine bluestained semithin sections, which were re-embedded and serially cut for TEM analysis, as shown in E-G, I, J, L, N, O and Q. E, endothelial cell. Scale bar in A (A-C) and E, $5 \mu \mathrm{m}$; D, $\mathrm{H}, \mathrm{K}, \mathrm{M}$ and $\mathrm{P}, 10 \mu \mathrm{m} ; \mathrm{F}$, J, and $\mathrm{O}, 1 \mu \mathrm{m} ; \mathrm{G}$ and $\mathrm{L}, 500 \mathrm{~nm} ; \mathrm{I}, \mathrm{N}$ and $\mathrm{Q}, 2 \mu \mathrm{m}$. 

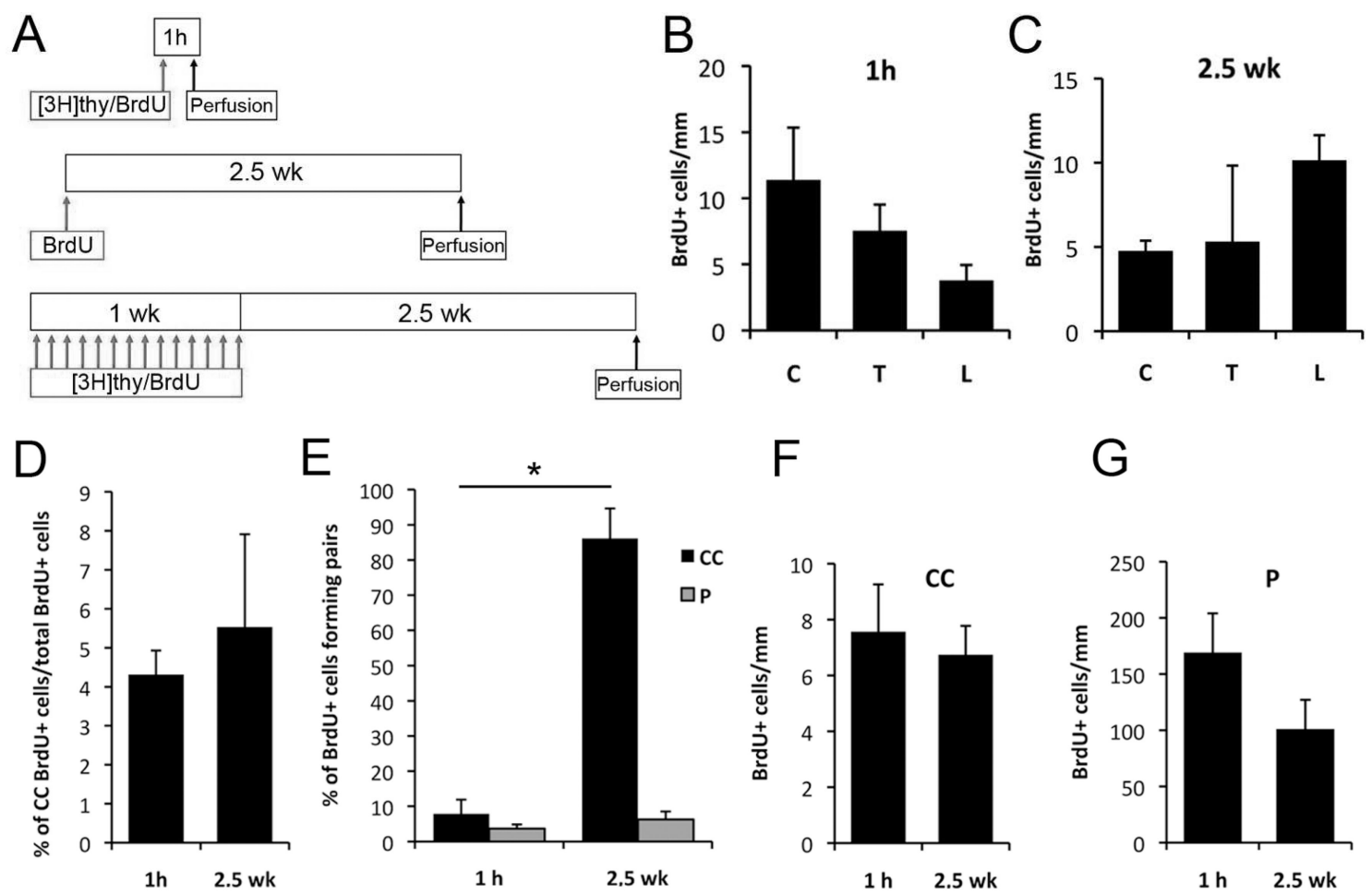

$\mathrm{F}$

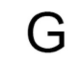

H
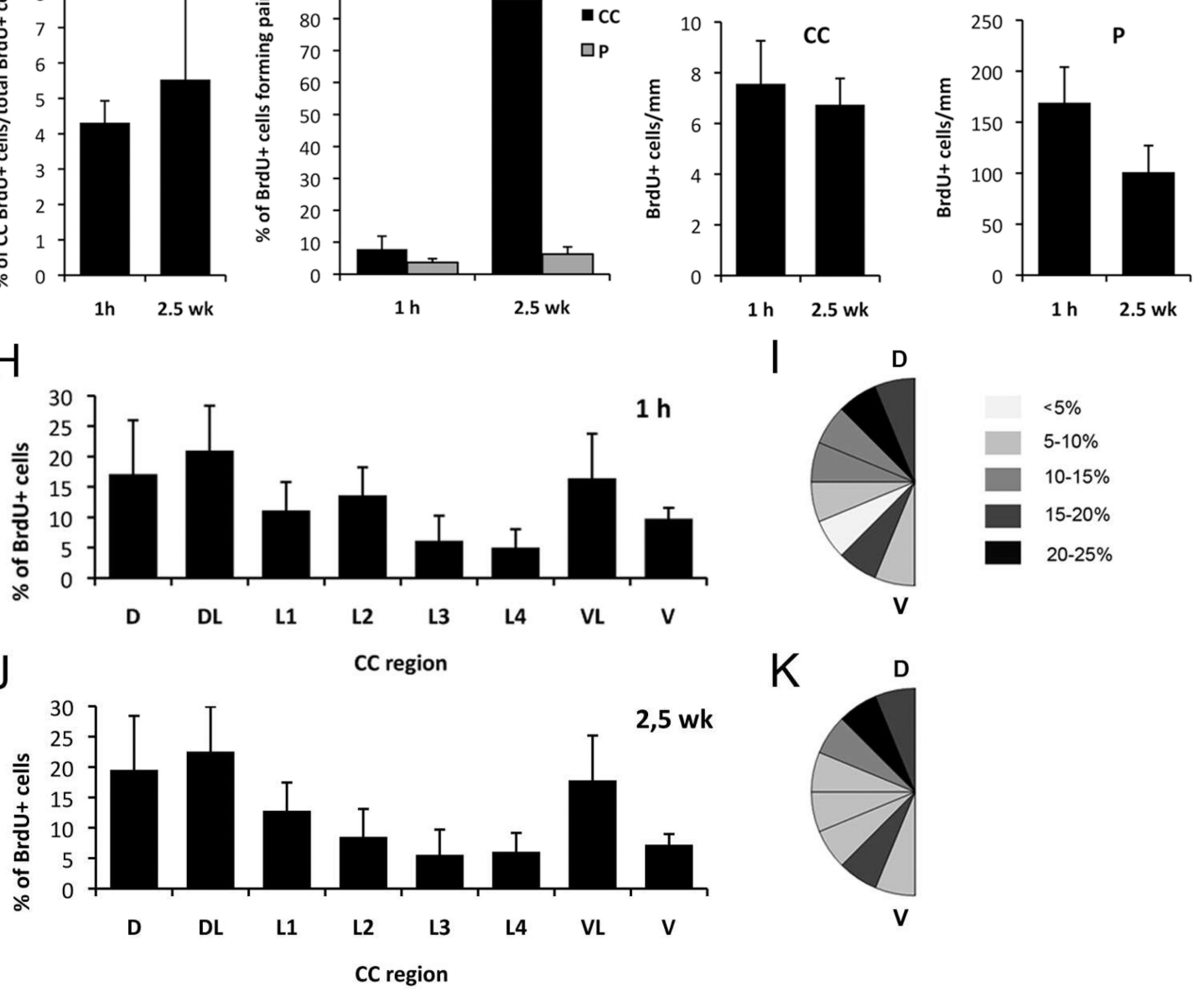

Figure 6. Proliferation along the spinal cord

A) BrdU and $\left[{ }^{3} \mathrm{H}\right]$ thymidine injection protocols. B-C) Proliferation in the central canal and in the parenchyma does not significantly vary along cervical, thoracic and lumbar regions, 1 hour (1 h) as well as 2.5 weeks (2.5 wk) after BrdU injection. D) In the spinal cord, the percentage of labeled cells in the canal from the total number of spinal cord labeled cells did not vary between the two studied protocols. E) More than $80 \%$ of labeled cells after 2.5 weeks are forming pairs in the central canal. F-G) In the spinal cord central canal and parenchyma, no differences were observed between labeled cell numbers after 1 hour or 2.5 weeks. H-K) Distribution of BrdU+ cells along the dorsoventral axis in the central canal 1 hour (H-I) and 2.5 weeks (J-K) after BrdU injection. Labeled cells concentrated in dorsal 
and ventral regions, and fewer cells were found in the lateral canal walls. This distribution was very similar in both groups of study. A-G) C, cervical; T, thoracic; L, lumbar; CC, central canal; P, parenchyma. H-K) CC, central canal; D, dorsal; DL, dorsolateral; L1-L4, lateral; VL, ventrolateral; V, ventral. Error bars show SEM. 

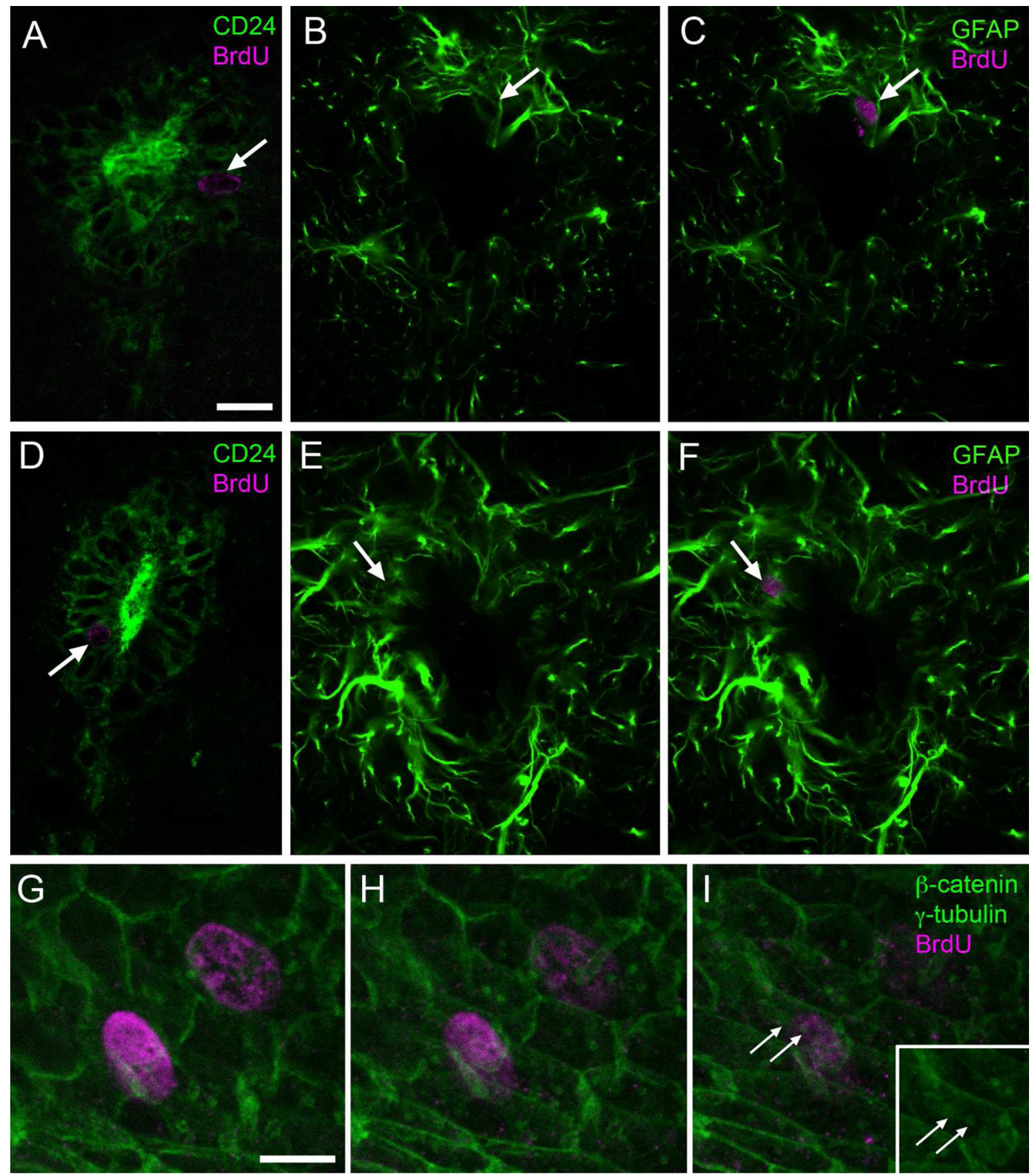

Figure 7. Identification of proliferating and generated cell types with immunofluorescence A-F) Most BrdU+ cells (arrows, magenta) 1 hour (A-C) or 2.5 weeks (D-F) after injection express CD24 and occasionally GFAP (green). E) Whole mount staining showed BrdU+ cells (magenta) with two basal bodies ( $\gamma$-tubulin, green, arrows). $\beta$-catenin is also shown in green. Scale bar in A (A-F), $10 \mu \mathrm{m} ; \mathrm{G}(\mathrm{G}-\mathrm{I}), 2 \mu \mathrm{m}$. 

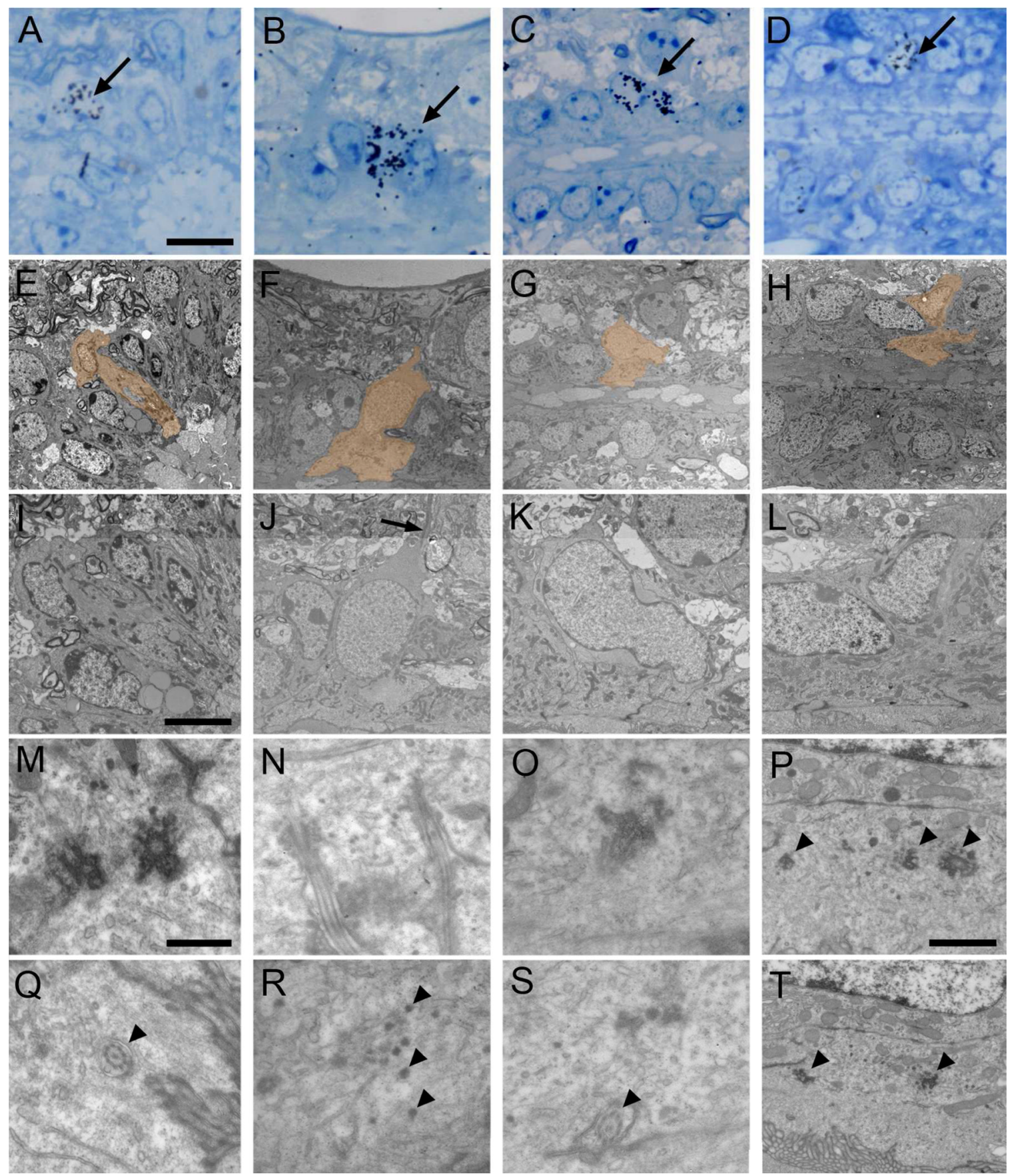

Figure 8. Identification of proliferating cell types with TEM

Autoradiography on animals sacrificed 1 hour after $\left[{ }^{3} \mathrm{H}\right]$ thymidine injection. Labeled cells were identified on toluidine blue-stained semithin sections (A-D, arrows), serial ultrathin sectioned and analyzed under the TEM (E-T). Electronmicrographs of cells pointed with an arrow and depicted in orange are shown. A) Labeled Ecc cell (E and I), showing apically two large and electron-dense basal bodies (M). In a different section, the 9+2 microtubule structure of the cilium can be observed (Q, arrowhead). B) A different biciliated Ecc cell identified on a longitudinal section $(\mathrm{F}$ and $\mathrm{J})$. It shows a radial expansion ( $\mathrm{J}$, arrow) and two cilia cut longitudinally $(\mathrm{N})$. Other sections of the reconstruction showed dense particles close to the basal bodies ( $\mathrm{R}$, arrowheads). C) Uniciliated Ecc cell labeled on a longitudinal 
section ( $\mathrm{G}$ and $\mathrm{K})$. The cell showed apically a cilium with a large electron-dense basal body (O) and 9+2 microtubule structure (S, arrowhead). D) Frequently, labeled ependymal cells ( $\mathrm{H}$ and $\mathrm{L}$ ) contained apically basal body portions and electron-dense particles $(\mathrm{P}$ and $\mathrm{T}$, arrowheads). Scale bar in A (A-H), $10 \mu \mathrm{m}$; I (I-L), $5 \mu \mathrm{m}$; M (M-O and Q-S), $500 \mathrm{~nm}$; P (P and $\mathrm{T}), 1 \mu \mathrm{m}$. 

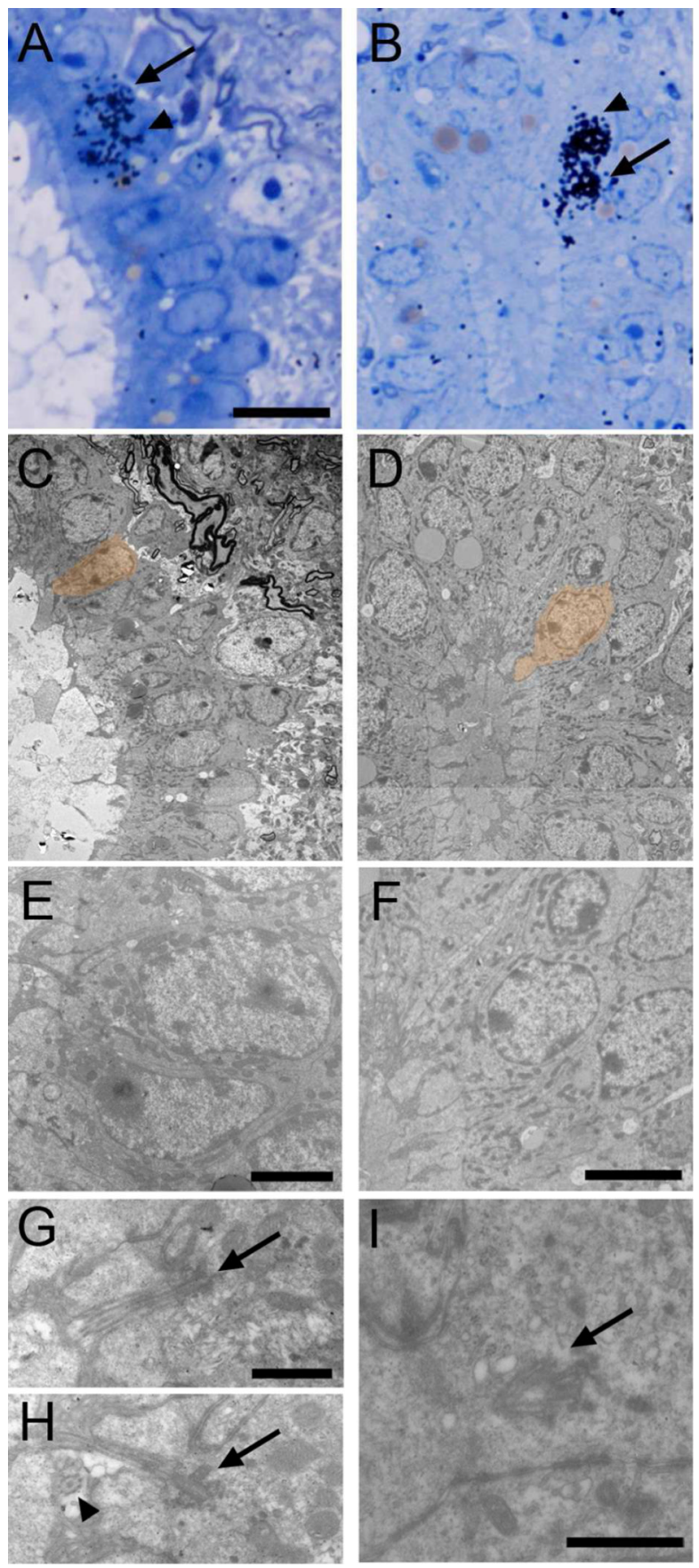

Figure 9. Identification of generated cell types with TEM

Autoradiography on animals sacrificed 2.5 weeks after $\left[{ }^{3} \mathrm{H}\right]$ thymidine injections. Labeled cells were identified on toluidine blue-stained semithin sections (A-B, arrows), serial ultrathin sectioned and analyzed under the TEM (C-I). Pairs of labeled cells were frequently observed (arrows and arrowheads). Electronmicrographs of cells pointed with an arrow and depicted in orange are shown. A) Labeled Ecc cell (C and E) with two cilia, appearing on two different ultrathin sections $(\mathrm{G}-\mathrm{H})$. These cilia showed 9+2 structure (arrowhead) and large basal bodies (arrows). B) Labeled uniciliated Ecc cell (D and F) showing the beginning of the cilium with a large basal body (I, arrow). Scale bar in A (A-D), $10 \mu \mathrm{m} ; \mathrm{E}, 2 \mu \mathrm{m} ; \mathrm{F}, 5$ $\mu \mathrm{m} ; \mathrm{G}(\mathrm{G}-\mathrm{H})$ and $\mathrm{I}, 1 \mu \mathrm{m}$. 

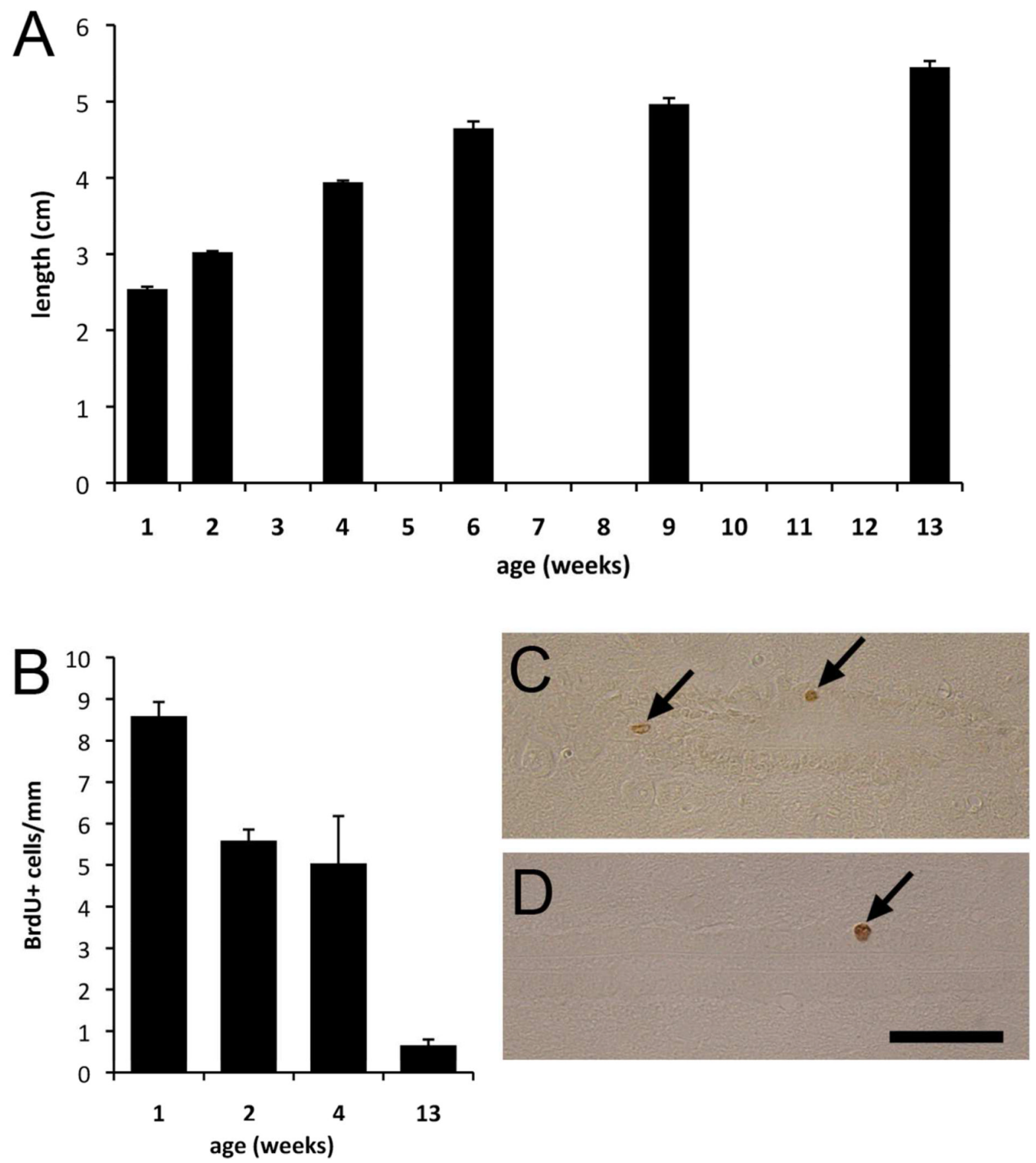

Figure 10. Spinal cord growth and proliferation

A) The spinal cord continues growing postnatally, but the length extension decreases progressively from 1 to 13 weeks. B) Central canal proliferation decreases with the animal's age. C-D) Longitudinal section showing BrdU labeled cells (arrows) in mice aged 2 (C) and 13 (D) weeks. Scale bar, $50 \mu \mathrm{m}$. Error bars show SEM. 

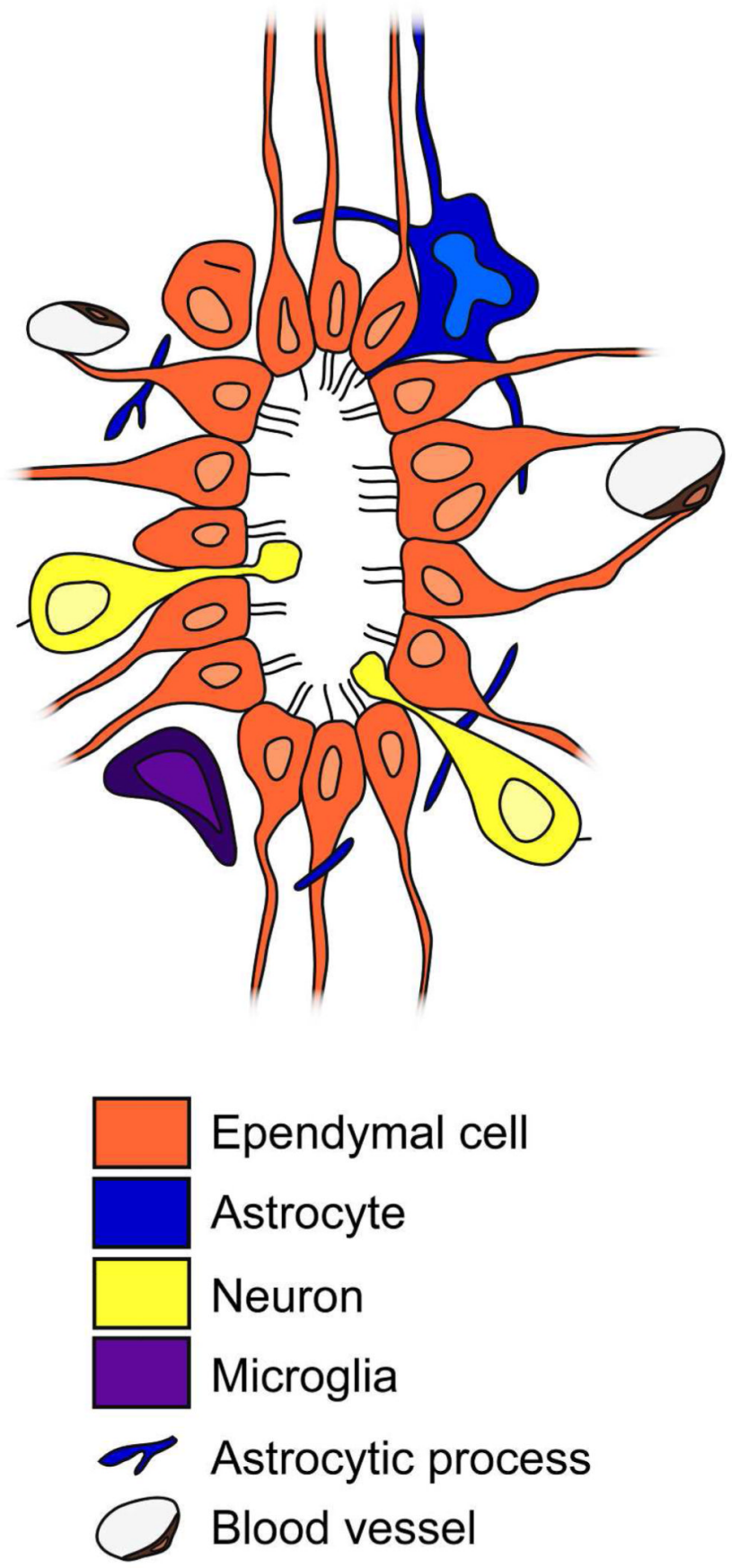

Figure 11. Model for the mouse central canal organization

Transverse schematic view showing the different cell types found in the central canal. We describe ependymal cells with up to four cilia, most frequently biciliated. Some binucleated cells are present. There are also astrocytes and neurons in contact with the canal lumen. Microglial cells and astrocytic processes surround the epithelium. Blood vessels are very close to the central canal, with an extensive basal lamina network. 
Table 1

Primary antibodies used in this study.

\begin{tabular}{|c|c|c|c|}
\hline Antigen & Immunogen & $\begin{array}{c}\text { Manufacturer, species, catalog } \\
\text { number }\end{array}$ & Dilution used \\
\hline BrdU & BrdU conjugated to bovine seroalbumin & $\begin{array}{l}\text { Dako (Glostrup, Denmark), mouse } \\
\text { monoclonal IgG, \#M0744 }\end{array}$ & $(1: 150)$ \\
\hline BrdU & BrdU & $\begin{array}{l}\text { Abcam (Cambridge, MA), rat } \\
\text { monoclonal IgG, \#ab6326 }\end{array}$ & $(1: 200)$ \\
\hline GFAP & GFAP isolated from cow spinal cord & Dako, rabbit polyclonal IgG, \#Z0334 & $(1: 1000)$ \\
\hline Vimentin & Human thymic nuclear extract & $\begin{array}{c}\text { Sigma-Aldrich (St. Louis, MO), mouse } \\
\text { monoclonal (clon LN6) IgM, \#V- } \\
2258\end{array}$ & $(1: 1000)$ \\
\hline CD24 & C57BL/10 Mouse splenic T Lymphocytes & $\begin{array}{l}\text { BD Biosciences (Franklin Lakes, NJ), } \\
\text { rat monoclonal (clon M1/69) } \\
\text { IgG2b, \#557436 }\end{array}$ & $(1: 500)$ \\
\hline Phospho-histone H3 & $\begin{array}{c}\text { KLH-conjugated peptide (ARK[pS]TG- GKAPRKQLC) } \\
\text { corresponding to } \\
\text { amino acids } 7-20 \text { of human histone H3 }\end{array}$ & $\begin{array}{l}\text { Millipore (Billerica, MA), rabbit } \\
\text { polyclonal IgG, \#06-570 }\end{array}$ & $(1: 500)$ \\
\hline Ki67 & $\begin{array}{l}\text { Prokaryotic recombinant fusion protein corresponding to } \\
\text { a } 1086 \mathrm{bp} \text { Ki67 motif- } \\
\text { containing cDNA fragment }\end{array}$ & $\begin{array}{l}\text { Novocastra (Newcastle Upon Tyne, } \\
\text { United Kingdom), mouse } \\
\text { monoclonal (clone MM1) IgG1, \#NCL- } \\
\text { L-Ki67-MM1 }\end{array}$ & $(1: 500)$ \\
\hline Y-tubulin & $\begin{array}{c}\text { Synthetic peptide corresponding to the N-terminal region } \\
\text { of human } \mathrm{Y} \text {-tubulin } \\
\text { (aa 38-53, with C-terminally added lysine) conjugated to } \\
\text { KLH }\end{array}$ & $\begin{array}{c}\text { Sigma-Aldrich, rabbit polyclonal, } \\
\text { \#T5192 }\end{array}$ & $(1: 1000)$ \\
\hline Y-tubulin & $\begin{array}{l}\text { Synthetic peptide conjugated to KLH, corresponding to } \\
\text { N-terminal aa } 38-53 \\
\text { of } Y \text {-tubulin }\end{array}$ & $\begin{array}{l}\text { Abcam, mouse monoclonal [GTU-88] } \\
\text { IgG1, \#AB11316 }\end{array}$ & $(1: 500)$ \\
\hline$\beta$-catenin & Mouse $\beta$-catenin aa 571-781 & $\begin{array}{l}\text { BD Biosciences, mouse monoclonal } \\
\text { (clone 14) IgG1, \#610153 }\end{array}$ & $(1: 500)$ \\
\hline$\beta$-catenin & $\begin{array}{c}\text { Synthetic peptide corresponding to aa } 768-781 \text { of human } \\
\text { or mouse } \beta \text {-catenin } \\
\text { conjugated to KLH as immunogen }\end{array}$ & $\begin{array}{l}\text { Sigma-Aldrich, Rabbit polyclonal IgG, } \\
\text { \#C2206 }\end{array}$ & $(1: 1000)$ \\
\hline GFP & Purified recombinant green fluorescent protein & $\begin{array}{l}\text { Aves Labs (San Diego, CA), chicken } \\
\text { polyclonal IgY, \#GFP-1020 }\end{array}$ & $(1: 200)$ \\
\hline NeuN & Purified cell nuclei from mouse brain & $\begin{array}{l}\text { Millipore, mouse monoclonal IgG (clone } \\
\text { A60), \#MAB377 }\end{array}$ & $(1: 500)$ \\
\hline DCX & $\begin{array}{c}\text { Synthetic peptide conjugated to KLH derived from } \\
\text { within residues } 300 \text { to the } \\
\text { C-terminus of human doublecortin; sequence } \\
\text { YLPLSLDDSDSLGDSM }\end{array}$ & $\begin{array}{c}\text { Abcam, rabbit polyclonal IgG, } \\
\text { \#AB18723 }\end{array}$ & $(1: 500)$ \\
\hline Nestin & Nestin purified from embryonic rat spinal cord & $\begin{array}{l}\text { Millipore, rat monoclonal IgG1, clone } \\
\text { Rat-401, \#MAB353 }\end{array}$ & $(1: 200)$ \\
\hline Sox2 & $\begin{array}{l}\text { Peptide corresponding to amino acids } 249-264 \text { of human } \\
\text { Sox2 } \\
\text { (SSSPPVVTSSSHSRAP; identical to mouse), affinity- } \\
\text { purified serum }\end{array}$ & $\begin{array}{c}\text { Millipore, rabbit polyclonal IgG, } \\
\text { \#AB5603 }\end{array}$ & $(1: 200)$ \\
\hline CD133 & Embryonic mouse telencephalic neuroepithelium & $\begin{array}{l}\text { eBioscience (San Diego, CA) rat } \\
\text { monoclonal IgG1, \#14-1331 }\end{array}$ & $(1: 100)$ \\
\hline
\end{tabular}

J Comp Neurol. Author manuscript; available in PMC 2013 September 19. 


\section{Table 2}

Morphological characteristics of the different cell types in the adult mouse central canal.

\begin{tabular}{cccc}
\hline & Ependymal & Astrocyte & Neuron \\
\hline CONTOUR & Smooth, radial & Interdigitated, radial & Smooth, apical expansion \\
CYTOPLASM & Dark & Light & Medium \\
NUCLEI & Round-oval & Irregular & Round \\
CHROMATIN & Small clumps & Clumped & Lax \\
NUCLEOLI & $3-4$ & $1-2$ & $1-2$ \\
RER & + & + & ++++ \\
GOLGI & +++ & + & +++ \\
MITOCHONDRIA & ++++ & ++ & +++ \\
FREE RIBOSOMES & + & ++ & ++++ \\
INTER. FILAMENTS & ++++ & ++ & No \\
MICROTUBULES & No & No & +++ \\
LIPID DROPLETS & Yes & No & No \\
CILIA & $1-4$ & 1 & 1 \\
MICROVILLI & Yes & Yes & No \\
\hline
\end{tabular}

These characteristics are based on serial section ultrathin reconstruction of the different cell types. RER, rough endoplasmic reticulum; +, few; ++, intermediate; +++, abundant; ++++, extremely abundant. 